\title{
ANALISIS PENGENDALIAN PENCEMARAN AIR DI ZONA HULU SUNGAI CITARUM DENGAN MODEL MULTI DIMENSIONAL SCALLING
}

\section{ANALYSIS OF WATER POLLUTION CONTROL IN THE UPPER CITARUM RIVER ZONE USING MULTI DIMENSIONAL SCALLING MODEL}

\author{
Iskandar A. Yusuf \\ Balai Lingkungan Keairan Pusat Penelitian dan Pengembangan Sumber Daya Air \\ JI. Ir. H. Juanda193 Bandung, Jawa Barat, Indonesia \\ E-mail: iayusuf@yahoo.com
}

Diterima: 19 Oktober 2015; Direvisi: Oktober 2015; Disetujui: 9 Februari 2016

\begin{abstract}
ABSTRAK
Sungai Citarum merupakan sungai terbesar di Provinsi Jawa Barat, yang karena tingginya fungsi dan manfaat sungai ini telah dibangun tiga waduk kaskade: Saguling-Cirata-Jatiluhur yang menghasilkan listrik sekitar 1.900 MW dan mengairi sawah irigasi teknis lebih dari 240.000 ha dan memasok air baku air minum untuk DKI Jakarta, melalui Saluran Tarum Barat, Tarum Timur dan Tarum Utara. Namun demikian, kondisi kualitas airnya sudah tercemar sangat berat. Berbagai upaya dimulai dari penataan peraturanperundangan dan institusi pelaksananya, dan telah banyak dilakukan berbagai program pemerintah untuk melakukan pengendalian pencemaran air, tetapi sungai Citarum tetap tidak mampu dipulihkan kondisi kualitas airnya, sebab di sisi lain perizinan pembuangan air limbah terus berjalan tanpa menghiraukan kondisi faktualnya. Penelitian ini bertujuan untuk menganalisis status keberlanjutan upaya pengendalian pencemaran air di Sungai Citarum Hulu dengan metode Multi Dimensional Scalling yang meliputi dimensi: Kebijakan, Teknis, Ekonomi, Sosial-Budaya, Penegakan Hukum dan Dukungan Pemangku Kepentingan, agar dapat disusun usulan solusinya. Hasil kajian pada kondisi eksisting tahun 2015, pada semua dimensi kurang berkelanjutan, namun untuk tahun 2030 dan 2050 diperkirakan cukup optimis sehingga dimensi teknis meningkat signifikan mencapai status sangat berkelanjutan yang diikuti oleh dimensi lainnya mencapai status cukup berkelanjutan. Hasil analisis menunjukkan adanya indikasi bahwa dimensi teknis dapat lebih terealisir dari pada dimensi lainnya dan yang tersulit adalah dimensi ekonomi.
\end{abstract}

Kata kunci: $\quad$ Kualitas air, pengendalian pencemaran air, Sungai Citarum, analisis status keberlanjutan, multi dimensional scalling

\section{ABSTRACT}

Citarum River is the largest river in West Java province, which due to high functionality and benefit of this river has been constructed three large cascade reservoirs: Saguling-Cirata-Jatiluhur that produce arround 1,900 MW electricity and irrigate the paddy fields with technical irrigation for DKI Jakarta over 240,000 ha and water supply through the West Tarum Canal, East Tarum Canal and North Tarum Canal. However, Citarum river is very polluted. Various efforts starting from laws and regulations as well as structuring of institution, and has been done several government programs establishing to control water pollution control. However, Citarum river can not be restorated properly due to disposal of wastewater still permits regardless of the factual condition. This study aimed at analysing the sustainability status of water pollution control in Citarum river by applying Multi Dimensional Scaling method covering the dimensions: Policy, Technical, Economic, Socio-Cultural, Law Enforcement and Stakeholders Support, in order to define a proposal for him solution. The results of the study for the existing condition in 2015 that in all dimensions less sustainable. However, for year 2030 and 2050 the so technical dimension increased significantly as a highly sustainable status followed by other dimensions achieving sustainable status. The analysis results indicated that a technical dimension can be more implemented than others, and the most difficult one is the economic dimension.

Keywords: Water quality, water pollution control, Citarum river, sustainability status analysis, multidimensional scaling 


\section{PENDAHULUAN}

Upaya pengendalian pencemaran air (PPA) secara legal di Indonesia telah mulai diperhatikan dengan dibuatnya Undang-undang No. 4 tahun 1982 tentang Ketentuan-ketentuan Pokok Pengelolaan Lingkungan Hidup, kemudian direvisi menjadi Undang-undang No. 23 Tahun 1992 tentang Pengelolaan Lingkungan Hidup dan saat ini menjadi Undang-undang No. 32 Tahun 2009 tentang Perlindungan dan Pengelolaan Lingkungan Hidup yang kemudian diikuti oleh berbagai aturan turunannya.

Sungai Citarum merupakan sungai terbesar dan terpanjang di Provinsi Jawa Barat yang bermanfaat sebagai sumber air baku baik untuk Kabupaten/Kota yang dilewatinya serta suplay air baku untuk DKI Jakarta. Karena tingginya ketergantungan terhadap sungai ini telah dibangun tiga waduk kaskade raksasa yaitu: Saguling-Cirata-Jatiluhur yang menghasilkan hampir 1.900 MW listrik sebagai sumber daya listrik nasional dan mengairi sawah irigasi teknis lebih dari 240.000 ha melalui Saluran Tarum Barat, Tarum Timur dan Tarum Utara (Pusat Litbang Sumber Daya Air, 2012). Pelaksanaan inventarisasi dan evaluasi sumber-sumber air telah dilakukan sejak tahun 1980-an dan kemudian Program Kali Bersih (Prokasih) sejak tahun 1990-an sebagai upaya untuk menurunkan beban pencemaran air dengan melakukan pemantauan efluen limbah yang harus memenuhi baku mutu limbah cair (BMLC), dan juga berbagai upaya PPA secara teknis melalui sosialisasi teknologi pengolahan air limbah dan pembuatan percontohan instalasi pengolahan air limbah (IPAL) untuk domestik dan juga industri secara gabungan untuk kawasan atau zona industri.

Disamping berbagai upaya dalam penataan peraturan-perundangan serta penataan institusi atau lembaga pelaksananya berbagai program pemerintah yang dengan giatnya berupaya untuk melakukan PPA dalam rangka pemulihan kualitas air pada sungai-sungai penting di Indonesia yang termasuk juga sungai Citarum. Namun konon pada tahun 2008, sungai Citarum telah didaulat sebagai sungai terkotor sedunia padahal berbagai program baik itu penelitian ataupun pembangunan infrastruktur terus berjalan dilaksanakan oleh berbagai institusi. Tetapi kenyataannya upayaupaya tersebut dirasakan belum mampu mendongkrak keterpurukan kondisi kualitas air sungai Citarum yang berstatus tercemar sangat berat sesuai dengan hasil pemantauan kualitas air sejak tahun 1990 yang menunjukkan tren semakin parah memburuknya kualitas air pada 25 tahun terakhir.
Berbagai hasil studi telah dipublikasikan yang menyatakan bahwa sungai Citarum telah tercemar sangat berat sehingga daya dukung lingkungan atau daya tampung beban pencemaran air (DTBPA) telah terlampaui, namun hampir tidak ada satupun rekomendasi program yang mampu dilaksanakan oleh para pemangku kepentingan, malahan disisi lain perizinan pembuangan limbah terus berjalan tanpa menghiraukan kondisi faktualnya. Sementara kondisi eksisting tingginya beban pencemaran air di Citarum yang didominasi oleh air limbah domestik $( \pm 10$ juta jiwa) dan industri (540 industri besar dan lebih dari 5.000 kegiatan UMKM)) tetapi perizinan kawasan permukiman terus berkembang dan bahkan cekungan Bandung ditetapkan sebagai koridor pengembangan industri tekstil nasional. Suatu keadaan yang ironis ketergantungan pemanfaatan yang begitu tinggi, namun kenyataan upaya PPA yang ada cenderung tidak terintegrasi serta kurang memperhatikan aspek keberlanjutan berbagai program dari masing-masing institusi yang akhirnya berakibat fatal yaitu tidak tercapainya target program PPA secara keseluruhan (Hooper, Bruce P., 2003). Dilihat dari tingkat parahnya pencemaran zona hulu sungai Citarum khususnya pada segmen 2 dan 3 merupakan ruas-ruas sungai yang terparah dikarenakan hampir 50\% beban pencemaran air pada daerah aliran sungai (DAS) Citarum berada di zona hulu pada dua segmen ini, sehingga jika segmen-segmen ini dapat diatasi akan memperbaiki kualitas air di zona tengah dan hilirnya (Pusat Litbang Sumber Daya Air, 2012), maka penelitian ini difokuskan di zona hulu Sungai Citarum. Untuk mengetahui rencana solusi pemulihan kualitas air sungai Citarum, penelitian ini bertujuan untuk menganalisis status keberlanjutan upaya PPA di Sungai Citarum menggunakan model Multi Dimensional Scalling (MDS) yang meliputi Dimensi: Kebijakan, Teknis, Ekonomi, Sosial-Budaya, Penegakan Hukum dan Dukungan Pemangku Kepentingan.

\section{KAJIAN PUSTAKA}

Pembangunan berkelanjutan memiliki tiga pilar utama, yaitu pilar ekonomi, ekologi dan sosial dengan prinsip pembangunan berkelanjutan: menjamin pemerataan dan berkeadilan sosial; menghargai keanekaragaman dengan prasyarat selalu tersedianya sumberdaya alam secara berkelanjutan dan dasar bagi keseimbangan tatanan lingkungan/ekosistem; mengutamakan pendekatan integratif terhadap kompleksnya keterkaitan antar sistem alam dan sistem sosial; dan meminta perspektif jangka panjang (Hasan, 2010). Dari pandangan lain, pembangunan berkelanjutan didefinisikan sebagai pembangunan 
yang dapat memenuhi kebutuhan generasi sekarang tanpa mengorbankan generasi yang akan datang untuk dapat memenuhi kebutuhannya (Soegandy dan Hakim 2007).

Implementasi konsep pembangunan berkelanjutan telah diterapkan pada banyak negara dan oleh berbagai lembaga dengan mengembangkan indikator keberlanjutan antara lain oleh Center for International Forestry Research (CIFOR) yang mengembangkan sistem pembangunan kehutanan berkelanjutan dengan mengintegrasikan aspek ekologi, ekonomi, sosial dan kelembagaan. CIFOR mengembangkan sistem pembangunan perikanan berkelanjutan dengan memadukan keberlanjutan ekologi, keberlanjutan ekonomi, keberlanjutan sosial dan keberlanjutan kelembagaan. Food and Agriculture Organization (FAO) mengembangkan indikator keberlanjutan untuk pembangunan wilayah pesisir berdasarkan aspek ekologi, ekonomi, sosial, kelembagaan, teknologi dan pertahanan keamanan (Edwarsyah, 2008).

Penelitian lain tentang keberlanjutan dilakukan oleh Ridwan (2006) yang menyertakan enam dimensi keberlanjutan yaitu: dimensi ekologis, ekonomis, sosial budaya, hukum, kelembagaan dan teknologi. Persamaan dengan penelitian ini adalah menggunakan analisis MDS, namun perbedaannya terletak pada analisis lanjutan yang dilakukan yang menggunakan analisis ekonometrika dan sistem dinamik pada usaha peternakan sapi perah di kawasan pariwisata Kabupaten Bogor. Pada penelitian ini, yang mempunyai tugas untuk melaksanakan kegiatan PPA diantaranya yaitu: Badan Pengelolaan Lingkungan Hidup Daerah (BPLHD) Provinsi Jawa Barat, Badan Pengendalian Lingkungan Hidup (BPLH) Kabupaten Bandung/Bandung Barat dan Kota Cimahi, Dinas Pengelolaan Sumber Daya Air (PSDA) Provinsi Jawa Barat, Balai Besar Wilayah Sungai (BBWS) Citarum dan Perusahaan Umum Jasa Tirta II (PJTII). Sehubungan dengan kegiatan PPA ini, masingmasing institusi mempunyai tugas dan fungsi untuk aspek teknisnya sebagai berikut.

Berdasarkan PerGub Jawa Barat No. 51 Tahun 2009, BPLHD Provinsi Jawa Barat mempunyai tugas pokok: menyelenggarakan urusan pemerintahan daerah bidang pengelolaan lingkungan hidup berdasarkan asas otonomi, dekonsentrasi dan tugas pembantuan. Dalam menyelenggarakan tugas pokonya mempunyai fungsi: Perumusan dan penetapan kebijakan teknis bidang pengelolaan lingkungan hidup daerah, Pemberian dukungan atas penyelenggaraan pemerintahan daerah bidang tata kelola lingkungan, pengendalian pencemaran lingkungan, konservasi SDA dan mitigasi bencana serta penataan hukum, kemitraan dan pengembangan kapasitas lingkungan, Pengkoordinasian dan pembinaan unit pelaksana teknis badan (UPTB).

Sedangkan BPLH Kabupaten/Kota yang sebagai contoh BPLH Kabupaten Bandung berdasarkan Perda No. 21 Tahun 2007 mempunyai tugas pokok: memimpin, mengatur, membina, mengendalikan, mengkoordinasikan dan merumuskan serta mempertanggungjawabkan kebijakan teknis penyusunan dan pelaksanaan kebijakan daerah yang bersifat spesifik di bidang pembinaan, pelayanan dan pengendalian lingkungan hidup. Untuk menyelenggarakan tugas pokok tersebut mempunyai fungsi: Perumusan kebijakan teknis, Pemberian dukungan atas penyelenggaraan pemerintahan daerah, Pembinaan dan pelaksanaan tugas.

Balai PSDA yang berada di bawah Dinas PSDA Propinsi Jawa Barat berdasarkan KepGub No. 61/2002 mempunyai fungsi: Pelaksanaan operasional pelayanan di bidang sumber daya air (SDA) yang meliputi pengelolaan data SDA, pemeliharaan serta perbaikan prasarana SDA, pengendalian dan pemanfaatan air dan sumber air; dan Pelaksanaan pelayanan teknis administratif. Kegiatan-kegiatan ini di bawah tugas pokok Dinas PSDA yang meliputi: Perumusan kebijakan operasional di bidang pengelolaan SDA; Pembinaan pelaksanaan operasional di bidang SDA meliputi pembinaan program, pembinaan konservasi dan pelestarian, pembinaan teknik, pembinaan pelaksanaan operasi dan pemeliharaan serta pembinaan pemanfaatan; Penyediaan fasilitas dan sistem investasi pengusahaan SDA; Pemberian perijinan pemanfaatan air dan SDA serta pelaksanaan pelayanan umum di bidang pengelolaan SDA; Fasilitasi pelaksanaan pengelolaan SDA; Pengawasan, pengendalian dan evaluasi pengelolaan SDA.

BBWS Citarum, berdasarkan PerMen PU No 21/PRT/M/2010 tentang Organisasi dan Tata Kerja Unit Pelaksana Teknis Kementerian Pekerjaan Umum yang mempunyai tugas: melaksanakan pengelolaan SDA wilayah sungai yang meliputi: perencanaan, pelaksanaan konstruksi, operasi dan pemeliharaan dalam rangka konservasi dan pendayagunaan SDA, pengendalian daya rusak air pada sungai, danau, waduk, bendungan dan tampungan air lainnya seperti: irigasi, air tanah, air baku, rawa, tambak dan pantai, serta mempunyai fungsi: Menyusun pola dan rencana pengelolaan; Menyusun rencana dan pelaksanaan penyuluhan kawasan lindung sumber air pada wilayah sungai; Melakukan pengelolaan SDA yang meliputi konservasi, pembangunan, pendayagunaan dan pengendalian 
daya rusak; Menyiapkan rekomendasi teknis dalam pemberian izin atas penyediaan, peruntukan, penggunaan dan pengusahaan SDA; Melaksanakan operasi dan pemeliharaan, pengelolaan sistem hidrologi dan pemberdayaan masyarakat.

PJT-II diberi wewenang memungut iuran eksploitasi dan pemeliharaan kepada para pengguna komersial dan hasil dana yang diperoleh digunakan untuk membiayai kegiatan operasi dan pemeliharaan prasarana SDA. Melalui pendiriannya, PJT-II tersebut mulai diterapkan user pay principle, meskipun hanya terbatas pada pemanfaat yang bersifat komersial saja seperti penggunaan air baku untuk air minum, air industri dan air untuk tenaga listrik. Berdasarkan PP No. 70 Tahun 2010, PJT-II merupakan Badan Usaha Milik Negara yang diberi tugas dan wewenang sebagai berikut:

a. Guna menyelenggarakan kegiatan usaha pengelolaan dan pendayagunaan air dan sumber air serta usaha lain yang berkaitan dengan air;

b. Melakukan usaha-usaha berdasarkan ketentuan PP dan peraturan perundangundangan;

c. Melakukan kegiatan usaha, penyediaan air baku air minum, listrik, pertanian, industri, penggelontoran dan lain lain;

d. Melakukan usaha pembangkitan dan penyaluran listrik PLTA Ir. H. Juanda, jasa konsultan dan usaha pemanfaatan lahan dan usaha lainnya dengan persetujuan menteri keuangan;

e. Menyediakan pelayanan bagi kemanfaatan umum dan sekaligus memupuk keuntungan berdasarkan prinsip pengelolaan perusahaan;

f. Melaksanakan kegiatan penelitian, pembangunan, rehabilitasi, $\mathrm{OP}$, pengusahaan dan pengendalian dalam rangka penyelenggaraan kegiatan usaha;

g. Menetapkan tarif besarnya iuran pembiayaan OP pengairan dan penjualan tenaga listrik, setelah di tetapkan oleh menteri.

Jika dilihat dari tugas dan fungsi institusiinstitusi tersebut, secara umum serupa sesuai dengan perannya masing-masing. Eksekutor seperti BBWS Citarum yang fokus kegiatannya ke operasional pengelolaan SDA yang dibiayai oleh pemerintah, sedangkan model Regulator seperti Balai PSDA, BPLHD Provinsi Jawa Barat, BPLH Kabupaten/Kota Bandung dan Cimahi yang fokus kegiatannya ke perumusan kebijakan dan pembinaan operasional yang dibiayai oleh pemerintah. Selanjutnya model lainnya yaitu Operator seperti PJT-II yang fokus kegiatannya ke operasional pengelolaan SDA yang juga mempunyai fungsi komersial yang hasil pungutan dana dari pelanggannya untuk membiayai pelaksanaan kegiatan keseluruhannya. Analisis keberlanjutan menggunakan perangkat lunak aplikasi Rapfish (The rapid appraisal of the status of fisheries) dengan metode Multi Dimensional Scalling (Kavanagh, 2001). Analisis dilakukan melalui beberapa tahap yaitu: 1) penentuan atribut keberlanjutan kegiatan; 2) penilaian setiap atribut dalam skala ordinal berdasarkan kriteria keberlanjutan setiap dimensi; dan 3) penyusunan indeks dan status keberlanjutan kegiatan. Setiap atribut pada masing-masing dimensi diberikan skor berdasarkan scientific judgment dari responden. Nilai skor dari masing-masing atribut dianalisis secara skala multidimensional untuk menentukan satu atau beberapa titik yang mencerminkan posisi keberlanjutan kegiatan yang dikaji relatif terhadap dua titik acuan yaitu titik baik (good) dan titik buruk (bad) dengan rentang skor sangat buruk $=0$ sampai baik $=4$. Melalui metode MDS, maka posisi titik keberlanjutan dapat divisualisasikan sumbu horizontal dan/atau sumbu vertikal dengan nilai indeks perkembangan diberi nilai skor 0\%-100\%. (Rachman, 2012)

\section{METODOLOGI}

Penelitian ini dilakukan sejak tahun 2012 s.d. 2015 yang bersamaan dilakukannya penelitian tingkat kondisi (kerusakan) daerah aliran sungai (DAS) pada tahun 2011-2012 yang kemudian dilanjutkan dengan fokus keberlanjutan PPA dalam rangka pemulihan kualitas air di Sungai Citarum. Adapun data yang digunakan untuk debit Sungai Citarum dari tahun 1990 s.d. 2010, dan data kualitas air Sungai Citarum dari tahun 1990 s.d. 2014 diambil dari kegiatan Balai Lingkungan Keairan-Pusat litbang SDA tahun 2015.

Pengolahan data skor kondisi upaya PPA di zona hulu Sungai Citarum dilakukan dengan model MDS yang menggunakan sub-program RAPFISH (Kavanagh, 2001). Metode MDS merupakan teknik analisis statistik berbasis komputer dengan menggunakan perangkat lunak statistik seperti SPSS, yang melakukan transformasi setiap atribut keberlanjutan untuk setiap dimensi tentang upaya PPA di Sungai Citarum (Rachman, 2012). Rancangan analisis ini didesain dengan enam dimensi yaitu: Dimensi Kebijakan, Teknis, Ekonomi, Sosial-Budaya, Penegakan Hukum dan Dukungan Pemangku kepentingan. Masing-masing dimensi tersebut dirinci menjadi berbagai aspek dan atribut seperti pada Tabel 1. Pada pemberian kuisioner kepada para responden, pada umumnya meminta nilai dummy yang dihitung berdasarkan hasil penilaian awal berdasarkan data tahun 20102012. Selanjutnya para responden harus mengisi data skor atau boleh juga nominal untuk masing- 
masing atribut tersebut pada kondisi eksisting 2015 dan harapan atau perkiraan di tahun 2030 serta 2050 berdasarkan pertimbangan kemungkinan upaya yang akan dapat diimplementasikan di tahun-tahun mendatang. Penilaian adalah nilai nominal yang dibulatkan ke bawah dalam \% atau skor berdasarkan program yang terimplementasi dibandingkan dengan target capaian pemenuhan baku mutu air (BMA). Sedangkan nilai skor yang akan dijadikan input analisis adalah nilai rata-rata nominal dari hasil penilaian para responden yang kemudian dikonversikan menjadi nilai skor.

Tabel 1 Rincian Atribut, Aspek dan Dimensi dari Upaya PPA di Zona Hulu Sungai Citarum

\begin{tabular}{|c|c|c|c|}
\hline No & Dimensi & Aspek & Atribut \\
\hline$(1)$ & $(2)$ & (3) & (4) \\
\hline \multirow[t]{3}{*}{1.} & \multirow{3}{*}{ 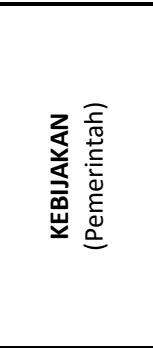 } & 1) Ketersediaan Peraturan-Perundangan & $\begin{array}{l}\text { - } \text { Undang-undang LH } \\
\text { - } \text { Kep.Men LH/Per.Men } \\
\text { - } \quad \text { Standar, Pedoman dan Manual }\end{array}$ \\
\hline & & $\begin{array}{l}\text { 2) Efektivitas Institusi/Lembaga dalam } \\
\text { pelaksanaan PPA }\end{array}$ & $\begin{array}{ll}\text { - } & \text { Men LH/(BPLHD/Dinas PSDA) Provinsi Jawa Barat } \\
\text { - } & \text { BPLH Kab/Kota Bandung dan Kota Cimahi } \\
\text { - } & \text { PJT-II } \\
\text { - } & \text { BBWS Citarum }\end{array}$ \\
\hline & & 3) Implementasi Program & $\begin{array}{l}\text { - } \text { Program Citarum, Prokasih s.d. Proper } \\
\text { - Percontohan Infrastruktur/teknologi } \\
\text { - } \text { Dana bantuan pusat untuk Pelaksanaan PPA }\end{array}$ \\
\hline \multirow[t]{4}{*}{2.} & \multirow{4}{*}{ 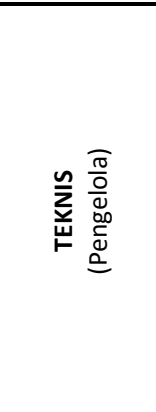 } & 1) Studi Pengelolaan Kualitas Air (PKA) & $\begin{array}{ll}\text { - } & \text { Rencana Pendayagunaan Air } \\
\text { - Status Mutu Air dan DTBPA }\end{array}$ \\
\hline & & 2) Peraturan BMLC Diperketat & $\begin{array}{l}\text { - } \text { Kep.Men LH/Per.Men } \\
\text { - } \text { Perda pengetatan BMLC dan perizinan } \\
\text { - } \text { Pengawasan Perda/PerBup yang lebih ketat }\end{array}$ \\
\hline & & 3) Peningkatan DTBPA & $\begin{array}{l}\text { - Pemanenan air hujan dan Sumur resapan } \\
\text { - Embung dan jebakan air } \\
\text { - Reboisasi }\end{array}$ \\
\hline & & 4) Penurunan Beban Pencemaran Air & $\begin{array}{ll}\text { - } & \text { Pengoperasian IPAL secara penuh } \\
\text { - } & \text { Industri bersih } \\
\text { - } & \text { Diversifikasi produk basah ke kering } \\
\text { - } & \text { Relokasi Sumber pencemar industri }\end{array}$ \\
\hline \multirow[t]{3}{*}{3.} & \multirow{3}{*}{ 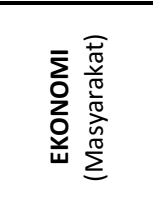 } & 1) Daya Beli Masyarakat & $\begin{array}{l}\text { - Peluang mendapatkan pekerjaan } \\
\text { - Upah yang layak }\end{array}$ \\
\hline & & 2) Imbal jasa lingkungan & $\begin{array}{l}\text { - Membiayai pengelolaan hutan di hulu } \\
\text { - Membiayai pemulihan daerah terkena dampak }\end{array}$ \\
\hline & & 3) Pemanfaatan limbah & $\begin{array}{l}\text { - Sisa limbah utk pupuk cair/gas methana } \\
\text { - Sisa lumpur utk bahan berguna }\end{array}$ \\
\hline \multirow[t]{4}{*}{4.} & \multirow{4}{*}{ 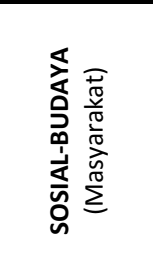 } & 1) Tingkat pendidikan masyarakat & $\begin{array}{ll}\text { - } & \text { Rata-rata lama sekolah (dalam tahun) } \\
\text { - } & \text { Kejuruan sesuai kebutuhan }\end{array}$ \\
\hline & & 2) Kepedulian lingkungan & $\begin{array}{l}\text { - } \text { Tingkat kepedulian thd. lingkungan } \\
\text { - Jumlah masyarakat yang peduli }\end{array}$ \\
\hline & & 3) Kontrol sosial masyarakat & $\begin{array}{l}\text { - } \text { Respon positif masyarakat } \\
\text { - } \text { Organisasi masa berbasis lingkungan }\end{array}$ \\
\hline & & 4) Dukungan thd. Kearifan lokal & $\begin{array}{l}\text { - } \text { Kreativitas lokal masyarakat } \\
\text { - Pelestarian kearifan lokal }\end{array}$ \\
\hline \multirow[t]{4}{*}{5.} & \multirow{4}{*}{ 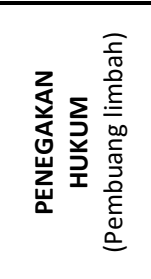 } & 1) Kejelasan peraturan & $\begin{array}{l}\text { - Peraturan sesuai kebutuhan stakeholder } \\
\text { - Transparan, efektiv dan proporsional }\end{array}$ \\
\hline & & 2) Ketegasan hukum & $\begin{array}{l}\text { - Pengawasan terhadap pelanggaran hukum } \\
\text { - Penindakan pelanggaran hukum }\end{array}$ \\
\hline & & 3) Pengawasan & $\begin{array}{ll}\text { - } & \text { Jumlah PPNS } \\
\text { - } & \text { Kompetensi PPNS } \\
\end{array}$ \\
\hline & & 4) Pengadilan & $\begin{array}{ll}\text { - Jumlah Jaksa } \\
\text { - Jumlah fasilitas pengadilan }\end{array}$ \\
\hline \multirow[t]{4}{*}{6.} & \multirow{4}{*}{ 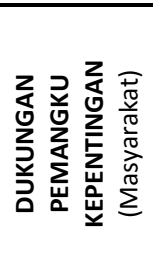 } & 1) Program PPA Partisipatif & $\begin{array}{l}\text { - } \text { Aktor pelaku yang komit melaksanakan PPA } \\
\text { - Dukungan thd masyarakat yang terkena dampak }\end{array}$ \\
\hline & & 2) Program CSR & $\begin{array}{ll}\text { - } & \text { CSR sesuai kebutuhan } \\
\text { - } & \text { CSR dengan biaya transparan \& efektiv }\end{array}$ \\
\hline & & 3) Program Advis teknis & $\begin{array}{l}\text { - } \text { Dukungan instansi terkait } \\
\text { - } \text { Advis teknis dan pembinaan teknologi }\end{array}$ \\
\hline & & 4) Sistem Informasi Lingkungan & $\begin{array}{l}\text { - } \text { Keakuratan informasi } \\
\text { - } \text { Kemutakhiran informasi }\end{array}$ \\
\hline
\end{tabular}



Atribut masing-masing aspek merupakan pelaksanaan berbagai kegiatan pada kolom (4) yang dapat dinilai 0\% -100\% sebagai nilai nominal prosentase yang linier atau dapat juga sebagai skala ordinal yang dibagi dalam 5 (lima) kelas skor yang secara umum yaitu: skor $=0$ : sangat buruk (tidak ada kegiatan), skor = 1: buruk (pelaksanaan kegiatan $<25 \%$ ), skor $=2$ : kurang (pelaksanaan kegiatan $\geq 25 \%-<50 \%$ ), skor $=3$ : cukup (pelaksanaan kegiatan $\geq 50 \%-<75 \%$ ) dan skor $=$ 4: baik (pelaksanaan kegiatan $\geq 75 \%$ ).

Goodness of fit dalam MDS dicerminkan dari besaran nilai $S$-Stress yang dihitung berdasarkan nilai $S$ dan $R^{2}$. Nilai stres yang rendah menunjukkan goodness of fit yang tinggi, sedangkan nilai $\mathrm{S}$ yang tinggi menunjukkan sebaliknya. Di dalam Rapfish, model yang baik jika $\mathrm{S}<0,25$, sedangkan nilai $\mathrm{R}^{2}$ yang baik adalah yang nilainya mendekati 1. Evaluasi pengaruh galat acak (Error) digunakan analisis Monte Carlo untuk mengetahui: (a) pengaruh kesalahan pembuatan skor atribut, (b) pengaruh variasi pemberian skor, (c) stabilitas proses analisis MDS yang berulangulang, (d) kesalahan pemasukan atau hilangnya data, dan $S$ nilai stress dapat diterima apabila < 20\% (Pitcher and Preikshot, 2001).

Selanjutnya proses analisis MDS akan menghasilkan nilai indeks keberlanjutan dan untuk menentukan kategorinya masing-masing dimensi berdasarkan Tabel 2.

Tabel 2 Kategori Status Keberlanjutan

\begin{tabular}{c|l}
\hline Nilai Indeks & \multicolumn{1}{|c}{ Kategori } \\
\hline 0 & Sangat tidak berkelanjutan \\
\hline$>0-<25$ & Tidak berkelanjutan \\
\hline $25-<50$ & Kurang berkelanjutan \\
\hline $50-<75$ & Cukup berkelanjutan \\
\hline $75-100$ & Berkelanjutan \\
\hline
\end{tabular}

Kemudian analisis leverage dalam MDS dilakukan untuk mengetahui atribut sensitif yang diperoleh berdasarkan nilai root mean square (RMS) ordinasi pada sumbu X, yaitu semakin besar perubahan RMS maka semakin sensitif peranan atribut tersebut terhadap peningkatan status keberlanjutan (Rachman, 2012).

Sedangkan untuk menganalisis faktor-faktor penentu keberlanjutan MDS dilakukan dengan menggunakan analisis prospektif dari faktor-faktor sensitif (leverage factor) yang dilakukan melalui tiga tahapan yaitu tahap pertama: penetuan faktor kunci pada kondisi saat ini (existing condition); tahap kedua: penentuan faktor-faktor kunci hasil analisis kebutuhan (need analysis) dari pemangku kepentingan dengan teknik Participatory Rural Appraisal dan wawancara atau isian kuesioner dengan para responden; tahap ketiga: penentuan faktor kunci dari hasil analisis gabungan antara hasil tahap pertama dan tahap kedua. Hasil analisis prospektif akan terlihat dalam diagram empat kuadran yang menggambarkan tingkat kepentingan faktor-faktor yang berpengaruh pada sistem yang dikaji. Faktor penentu atau penggerak (driving factors) adalah faktor-faktor yang mempunyai pengaruh kuat tetapi ketergantungannya kurang kuat, sehingga termasuk ke dalam kategori faktor paling kuat dalam sistem yang dikaji. Leverage factors akan menunjukkan pengaruh dan ketergantungan yang kuat, Output factors sebagai faktor terikat yang mewakili output yaitu faktor yang pengaruhnya kecil tetapi ketergantungannya tinggi. Sedangkan Marginal factors sebagai aktor bebas yaitu faktor yang pengaruh maupun tingkat ketergantungannya rendah, sehingga dalam sistem bersifat bebas (Rachman, 2012).

\section{HASIL DAN PEMBAHASAN}

Seperti dijelaskan di atas, bahwa dalam penelitian ini menyertakan empat model institusi yaitu: Esekutor seperti BBWS Citarum; Regulator seperti Balai PSDA, BPLHD Provinsi Jawa Barat, BPLH Kabupaten/Kota Bandung dan Kota Cimahi; dan Operator seperti PJT-II. Sesuai dengan metodologi untuk menganalisis keberlanjutan upaya PPA di zona hulu sungai Citarum ini yaitu telah dilakukan diskusi teknis kepada 4 Instansi pemerintah/BUMN (untuk mengisi sebanyak 4 x 3 kuesioner) dan memberikan 23 kuesioner kepada 5 (lima) kelompok calon responden yaitu: 1) Instansi pemerintah yang menangani lingkungan sebanyak 4 x 2 kuesioner, 2) Pakar Lingkungan dari Perguruan Tinggi sebanyak 3 x 2 kuesioner, 3) Praktisi Lingkungan sebanyak 3 x 1 kuesioner, 4) Konsultan Lingkungan sebanyak 3 x 1 kuesioner dan 5) LSM yang mengkritisi Lingkungan Citarum sebanyak 3 x 1 kuesioner. Namun yang sempat melakukan diskusi teknis dan yang mengembalikan hanya sebanyak 15 kuesioner dan yang dianggap memenuhi syarat dari hasil diskusi teknis dan isian kuesionernya hanya 12 responden saja dan beruntung juga masing-masing model atau kelompoknya telah terwakili.

Berdasarkan hasil diskusi teknis dan isian kuesioner, maka didapatkan hasil analisis status keberlanjutan upaya PPA di Sungai Citarum untuk masing-masing dimensi adalah sebagai berikut:

\section{Status Keberlanjutan Dimensi Kebijakan}

Dimensi kebijakan menyertakan 10 atribut yang dikelompokan dalam tiga aspek seperti pada Tabel 1. Hasil perhitungan rata-rata skor yang secara rinci disajikan pada Tabel 3. Nilai skor dari responden secara umum 41,7\% mendekati nilai 
Tabel 3 Hasil Kuesioner Dimensi Kebijakan Tahun 2015, Perkiraan Tahun 2030 dan 2050

\begin{tabular}{|c|c|c|c|c|c|}
\hline Dimensi & Aspek & Atribut & $\begin{array}{c}N_{a} \\
\text { Eksisting } \\
2015 \\
\end{array}$ & $\begin{array}{c}N_{a} \\
\text { Perkiraan } \\
2030 \\
\end{array}$ & $\begin{array}{c}N_{a} \\
\text { Perkiraan } \\
2050 \\
\end{array}$ \\
\hline$(1)$ & $(2)$ & (3) & $(4)^{4)}$ & $(5)^{4)}$ & $(6)^{4)}$ \\
\hline \multirow{3}{*}{ 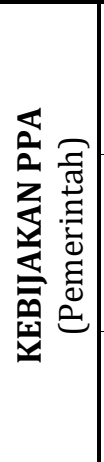 } & $\begin{array}{l}\text { 1) } \begin{array}{l}\text { Ketersediaan } \\
\text { Peraturan- } \\
\text { Perundangan }\end{array} \\
\end{array}$ & $\begin{array}{l}\text { - Undang-undang LH } \\
\text { - Kep.Men LH/Per.Men } \\
\text { - Standar, Pedoman dan Manual 1) }\end{array}$ & $\begin{array}{l}2,82 \\
3,24 \\
2,41\end{array}$ & $\begin{array}{l}3,14 \\
3,33 \\
3,15\end{array}$ & $\begin{array}{l}3,34 \\
3,34 \\
3,42\end{array}$ \\
\hline & \begin{tabular}{|l|} 
2) Efektivitas \\
Institusi/lembaga \\
dalam PPA \\
\end{tabular} & $\begin{array}{l}\text { - Men LH/BPLHD/Dinas PSDA } \\
\text { - BLH Kab/Kota } \\
\text { - PJT-II } \\
\text { - BBWS Citarum }\end{array}$ & $\begin{array}{l}2,38 \\
2,21 \\
2,38 \\
1,37\end{array}$ & $\begin{array}{l}2,92 \\
3,08 \\
3,52 \\
2,64\end{array}$ & $\begin{array}{l}3,24 \\
3,62 \\
3,85 \\
2,82\end{array}$ \\
\hline & $\begin{array}{l}\text { 3) Implementasi } \\
\text { Program PPA }\end{array}$ & $\begin{array}{l}\text { - Citarum, Prokasih s.d Proper } \\
\text { - Contoh infrastruktur PPA } \\
\text { - Dana bantuan upaya PPA }\end{array}$ & $\begin{array}{l}1,24 \\
1,42 \\
1,32\end{array}$ & $\begin{array}{l}2,13 \\
1,84 \\
1,87\end{array}$ & $\begin{array}{l}2,84 \\
2,42 \\
2,54\end{array}$ \\
\hline
\end{tabular}

Peningkatan jumlah standar dan pedoman mendukung tercapainya program PPA

2) Penambahan struktur organisasi khusus penanganan PPA pada instansi PJT-II dan BBWS Citarum

3) Implementasi program PPA

4) Nilai $N_{a}$ rata-rata aritmatik dari seluruh responden
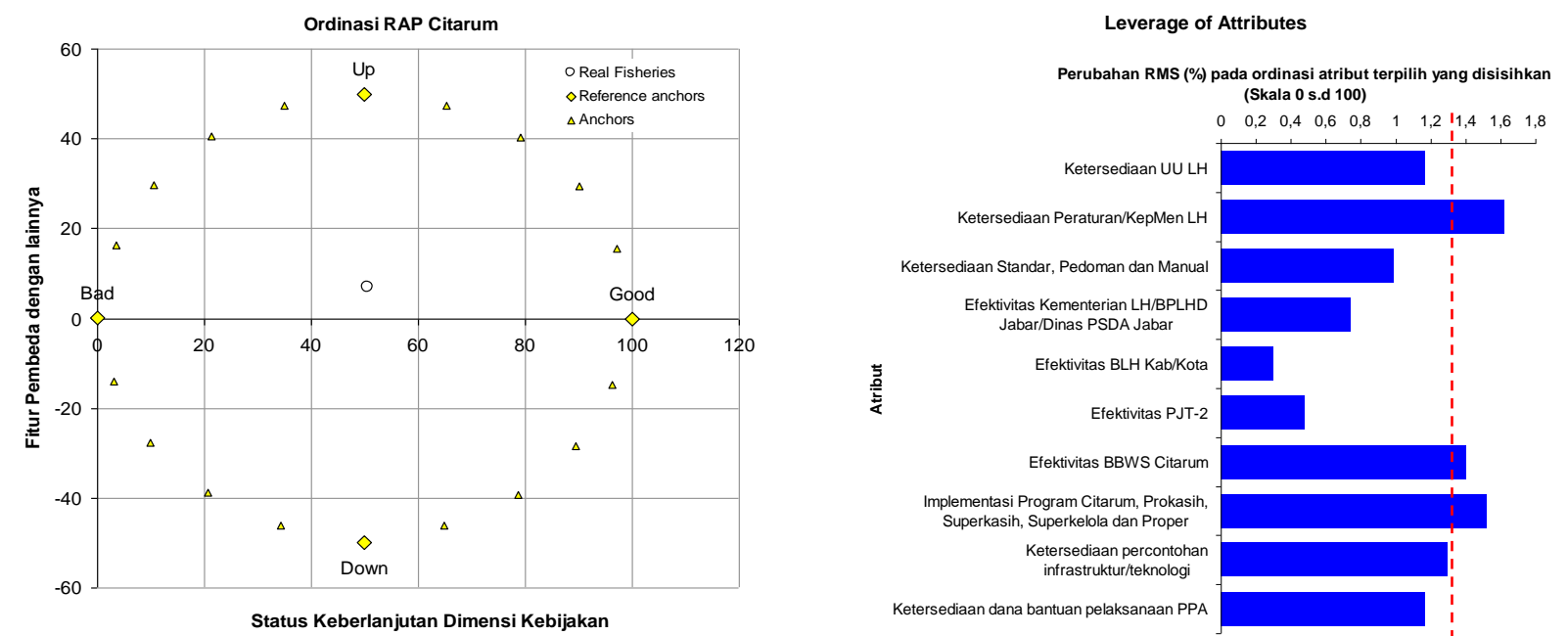

Gambar 1 Indeks Keberlanjutan Dimensi Kebijakan Tahun 2015

dummy, sementara yang di bawah nilai dummy sekitar $27,1 \%$ dan yang di atas nilai dummy yaitu sekitar 31,2\%. Selanjutnya hasil rata-rata skor dijadikan input pada aplikasi MDS yang menghasilkan ilustrasi parameter keberlanjutan seperti pada Gambar 1.

Hasil analisis MDS untuk Dimensi Kebijakan pada tahun 2015 (input dari Tabel 3, kolom 4) adalah $I_{k}=46,52 \%$ (kurang berkelanjutan) dengan nilai stress: $S_{k}=0,1295$ (memenuhi $<0,25$ ) dan $R^{2}=$ 0,9334 (sangat bermakna pada $\mathrm{p}<0,002$ ). Hasil analisis leverage diambil tiga atribut sensitif adalah: Ketersediaan Per.Men LH, Implementasi program Citarum - Prokasih - SuperKasih SuperKelola - Proper, dan Efektivitas BBWS Citarum. Kalau dilihat masing-masing atribut tersebut adalah mewakili masing-masing aspeknya. Aspek peraturan-perundangan menyertakan tiga atribut yaitu: ketersediaan Undang-undang Lingkungan Hidup sejak tahun 1982 dan yang saat ini berlaku yaitu UU No. 32 Tahun 2009 tentang Perlindungan dan Pengelolaan Lingkungan Hidup. Undang-undang ini secara substantif sangat ketat mengatur berbagai aspek lingkungan hidup. Kemudian atribut berikutnya KepMen LH atau PerMen merupakan rincian pengaturan yang lebih detail serta berbagai standar, pedoman dan manual yang secara keseluruhan kondisi saat ini sudah cukup lengkap dan detail yaitu sekitar 70\% - 75\% dari total kebutuhan substantifnya.

Institusi atau lembaga yang menyertakan empat institusi untuk dikaji sebagai pelaksana PPA di Sungai Citarum, yang salah satu mandatnya untuk melaksanakan kegiatan PPA dalam rangka pemulihan kualitas air Sungai Citarum. Namun 
dalam kenyataannya institusi ini belum berjalan baik atau belum bersinergi satu sama lain, apakah karena terlalu sempitnya lingkup kewenangan sektornya ataukah kurangnya SDM yang kompeten atau juga dikarenakan terlalu kompleknya permasalahan yang perlu dihadapi. Terkait hal ini telah dikaji untuk 4 alternatif model institusi ini (Tabel 3 kolom 3 untuk aspek 2) dengan model AHP (analitycal hierarcy procceses) yang hasilnya bahwa 4 alternatif model institusi tersebut semuanya kurang memenuhi syarat sehingga perlu dibentuk Tim Ad Hoc "Pemulihan Kualitas Air Sungai Citarum" untuk melaksanakan PPA Citarum dan selanjutnya kemungkinan akan menunjuk PJTII atau BBWS Citarum sebagai pelaksana operasional pengelolaan kualitas air sedangkan BPLHD dan/atau BPLH Kabupaten/Kota tetap sebagai regulator dan/atau sebagai pengawas. Untuk hal ini PJT-II mempunyai kelebihan dari lainnya yaitu mempunyai akses lintas sektor (Pusat Litbang SDA, 2015).

Implementasi program PPA ini seyogianya dilaksanakan sepenuhnya oleh pemerintah daerah sedangkan pemerintah pusat memberikan berbagai percontohan atau stimulan. Dalam implementasi ini menyertakan tiga atribut yaitu: 1) Berbagai program yang telah dilaksanakan di Citarum seperti Citarum Bergetar s.d. Citarum Bestari, Prokasih, SuperKasih, SuperKelola dan Proper; 2) Percontohan infrastruktur/teknologi seperti untuk limbah domestik telah dibangun IPAL Domestik di Bojongsoang, IPLT di Majalaya, Ciparay dan Soreang. Demikian juga untuk limbah industri telah dilakukan studi kluster industri Majalaya, Rancaekek, Ujungberung, Banjaran, Cimahi dan bahkan kluster Mohammad Toha telah dibangun IPAL Industri terpadu di Cisirung, dan 3) Program dana bantuan PPA sebagai stimulan yang kemudian agar terus dilanjutkan oleh pemerintah daerah.

Disamping program pemerintah ada juga program pemerintah provinsi seperti: Citarum Bergetar pada awal tahun 2000-an yang tidak berjalan sampai tuntas dan pada dua tahun terakhir ini ada program Citarum Bestari (Bersih, Sehat dan Lestari) yang seharusnya pada akhir tahun 2015 ini sudah sampai KM 70-an (KM 0 di Situ Cisanti) atau kira-kira sampai lokasi Nanjung sebagai akhir segmen-3. Implementasi program mungkin sudah mencapai lebih dari 80\%-nya namun hal ini masih belum terlihat adanya kebijakan yang secara rinci untuk pemenuhan BMA setiap ruas sungai Citarum.

Disisi lain terkait infrastruktur di BBWS Citarum ada kegiatan yang berhubungan dengan PPA yaitu pembangunan cek dam yang baru diselesaikan sekitar 100 buah cek dam dari program \pm 260 buah cek dam di Citarum Hulu.
Mungkin hal ini juga berarti belum tersusunnya suatu program rinci bersama dengan fokus untuk melakukan PPA secara konprehensif yang masingmasing institusi mempunyai tusi dan anggaran yang jelas harus melaksanakan rincian tugas prioritas untuk PPA Citarum secara bertahap yang detail.

Berdasarkan uraian di atas, pelaksanaan dimensi kebijakan khususnya untuk ketersediaan peraturan-perundangan dan efektivitas institusi /lembaga yang dinilai oleh responden rata-ratanya $60 \%$, sedangkan untuk implementasi program percontohan PPA dinilai responden rata-ratanya 33\%. Padahal kalau dinilai dari yang seharusnya dilakukan oleh pemerintah daerah masih sangat sedikit sekali yaitu hanya kurang dari 10\% yaitu paling juga pengawasan wajib bangun IPAL untuk industri sudah sangat baik yang sudah mencapai > 90\% telah mengoperasikan IPAL. Berdasarkan hasil analisis ini yaitu indeks keberlanjutannya "Kurang berkelanjutan" sesuai dengan realitanya "Sangat Buruk" dalam 25 tahun terakhir.

Perkiraan yang mungkin dapat dilakukan pada tahun 2030 dan tahun 2050, para responden kelihatannya sedikit optimis diwaktu mendatang terlihat adanya harapan peningkatan upaya walaupun kenyataannya sangat sulit untuk diperkirakan sehubungan dengan kinerja operasional pelaksanaan PPA di Citarum selama ini sangat kurang. Berdasarkan hasil kuesioner, yang dijadikan input pada analisis MDS yaitu pada Tabel 3 kolom 5 menghasilkan bahwa pada tahun 2030, $I_{k}=61,47 \%$ (cukup berkelanjutan) dengan nilai stress: $S_{k}=0,1482$ (memenuhi $<0,25$ ) dan $R^{2}=$ 0,9435 (sangat bermakna pada $\mathrm{p}<0,001$ ). Selanjutnya input dari Tabel 3 kolom 6 menghasilkan bahwa pada tahun 2050 adalah: $I_{k}=$ 69,49\% (cukup berkelanjutan) dengan nilai stress: $S_{k}=0,1419$ (memenuhi $<0,25$ ) dan $R^{2}=0,9476$ (sangat bermakna pada $\mathrm{p}<0,001$ ).

Berdasarkan hasil analisis leverage yang diambil tiga atribut sensitive, hasilnya masih sama dengan kondisi eksisting. Hasil ini memberikan indikasi bahwa tuntutan seharusnya adalah perlunya peningkatan implementasi peraturan perundangan, yang kemudian melanjutkan pelaksanaan program-program PPA bukan hanya sebatas pada waktu pelaksanaan program saja dan efektivitas BBWS Citarum. Ini suatu indikasi yang sangat logis perlunya peningkatan peran BBWS Citarum khususnya membangun infrastruktur PPA karena dinilai masih sangat kurang.

\section{Status Keberlanjutan Dimensi Teknis}

Dimensi teknis menyertakan 12 atribut yang dikelompokan dalam 4 aspek seperti pada Tabel 1 . Hasil perhitungan rata-rata skor yang didapatkan 
Tabel 4 Hasil Kuesioner Dimensi Teknis pada tahun 2015, Perkiraan tahun 2030 dan 2050

\begin{tabular}{|c|c|c|c|c|c|}
\hline Dimensi & Aspek & Atribut & $\begin{array}{c}N_{a} \\
\text { Eksisting } \\
2015\end{array}$ & $\begin{array}{c}N_{a} \\
\text { Perkiraan } \\
2030\end{array}$ & $\begin{array}{c}N_{a} \\
\text { Perkiraan } \\
2050\end{array}$ \\
\hline (1) & (2) & (3) & (4) & (5) & (6) \\
\hline \multirow{4}{*}{ 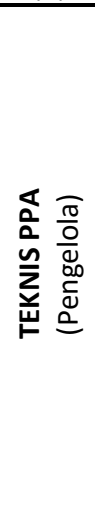 } & 1) Persiapan PPA & $\begin{array}{l}\text { - Rencana Pendayagunaan Air } \\
\text { - Status Mutu Air dan DTBPA }\end{array}$ & $\begin{array}{l}1,12 \\
3,15\end{array}$ & $\begin{array}{l}2,12 \\
3,34\end{array}$ & $\begin{array}{l}3,75 \\
3,85\end{array}$ \\
\hline & 2) Memperketat BMLC & $\begin{array}{l}\text { - Per.Men LH } \\
\text { - Perda BMLC untuk perizinan } \\
\text { - Pengawasan Perda/PerBup }\end{array}$ & $\begin{array}{l}0,52 \\
0,81 \\
1,14\end{array}$ & $\begin{array}{l}1,85 \\
1,51 \\
1,86\end{array}$ & $\begin{array}{l}2,84 \\
2,34 \\
2,25\end{array}$ \\
\hline & $\begin{array}{l}\text { 3) Memperbesar } \\
\text { DTBPA }\end{array}$ & $\begin{array}{l}\text { - Pemanenan air hujan dan/atau sumur } \\
\text { resapan air } \\
\text { - Embung dan jebakan air } \\
\text { - Reboisasi }\end{array}$ & $\begin{array}{l}0,52 \\
1,14 \\
0,84\end{array}$ & $\begin{array}{l}2,24 \\
2,13 \\
1,25\end{array}$ & $\begin{array}{l}3,12 \\
2,58 \\
1,87\end{array}$ \\
\hline & $\begin{array}{l}\text { 4) Mereduksi Beban } \\
\text { Pencemar }\end{array}$ & $\begin{array}{l}\text { - Pengoperasian penuh IPAL } \\
\text { - Industri bersih } \\
\text { - Diversifikasi basah ke kering } \\
\text { - Relokasi pencemar industri }\end{array}$ & $\begin{array}{l}2,22 \\
1,41 \\
1,82 \\
0,88\end{array}$ & $\begin{array}{l}3,15 \\
2,25 \\
2,76 \\
1,75\end{array}$ & $\begin{array}{l}3,74 \\
2,85 \\
3,24 \\
2,82\end{array}$ \\
\hline
\end{tabular}
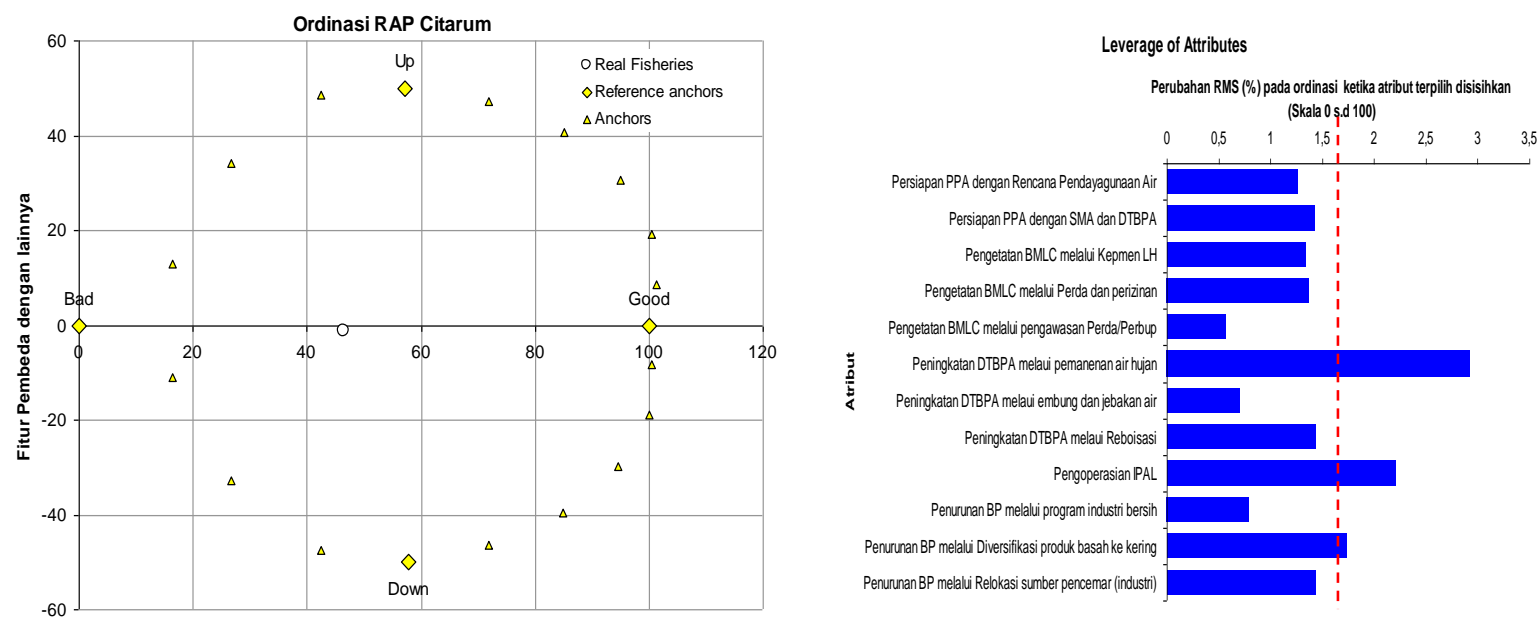

Gambar 2 Indeks Keberlanjutan Dimensi Teknis Tahun 2015

dari para responden secara rinci disajikan pada Tabel 4. Nilai skor secara umum 45,4\% mendekati nilai dummy, sementara yang di bawah nilai dummy sekitar $24,2 \%$ dan yang di atas nilai dummy yaitu sekitar 30,4\%. Selanjutnya hasil rata-rata skor dijadikan input pada aplikasi MDS. Hasil analisis MDS untuk kondisi eksisting (tahun 2015) yang diambil dari Tabel 4 kolom 4, seperti pada Gambar 2. Hasil analisis MDS untuk dimensi teknis pada tahun 2015 adalah: $I_{k}=46,50 \%$ (kurang berkelanjutan) dengan nilai stress: $S_{k}=0,1295$ (memenuhi $<0,25$ ) dan $R^{2}=0,9334$ (sangat bermakna pada $\mathrm{p}<0,002$ ). Jika melihat hasil analisis Leverage pada Gambar 2, diambil tiga atribut sensitif yaitu: Peningkatan DTBPA melalui pemanenan air hujan/sumur resapan air, Pengoperasian penuh IPAL dan Mereduksi beban pencemaran melalui diversifikasi produk basah ke kering.
Dalam kegiatan Studi PKA menyertakan dua atribut yaitu: Rencana Pendayagunaan Air, dan Status mutu air dan DTBPA. Seperti halnya pemberlakuan peraturan BMLC yang diperketat untuk daerah-daerah yang sudah padat oleh permukiman dan industri sangatlah sulit badan air memenuhi BMA-nya apalagi jika DTBPA-nya telah terlampaui. Di dalam penelitian ini menyertakan atribut: Pengetatan BMLC melalui PerMen LH, Perda BMLC dalam rangka perizinan pembuangan air limbah serta pengawasan pemberlakuan Perda/PerBup/ PerWal atau PerGub.

Aspek berikutnya yaitu memperbesar DTBPA yang dimaksudkan adalah memperbesar debit minimum di badan air sungai melalui upaya konservasi air dan lahan yang menyertakan atribut: pemanenan air hujan, pembangunan embung \& jebakan air serta reboisasi. Sebetulnya sasaran akhir dari atribut ini adalah reboisasi, yang 
dikarenakan proses ini akan membutuhkan waktu sangat lama maka pembangunan embung atau jebakan air ini sebagai sasaran antara untuk mempercepat prosesnya (Sabiham, S. 2005). Berbagai upaya untuk mensosialisasikan pemanenan air hujan dan sumur resapan sudah sangatlah banyak namun masih sedikit yang melakukan hal ini. Upaya konservasi ini biayanya sangat murah untuk skala perumahan namun jika dilaksanakan manfaatnya akan sangat besar apalagi jika dilakukan secara masal. Malahan pembangunan embung dan jebakan air biayanya sangat besar tetapi untuk capaian memperbesar debit tidak terlalu dapat diharapkan karena pembangunan embung ini sendiri cukup sulit apalagi untuk membangun dengan luasan dan jumlah yang besar.

Upaya untuk mereduksi beban pencemar yang sudah sering dibahas baik secara teknologi IPAL ataupun proses industri bersih, namun seringnya sangat terkendala oleh biaya yang mahal serta best available technology saat ini baru sampai tingkat sekunder dengan efisiensi maksimum 85\%, sedangkan influen yang harus diolah misalkan industri tekstil dalam kisaran kadar pencemar 400 - $800 \mathrm{mgBOD} / \mathrm{L}$ sehingga rentang efluennya hanya mampu 60 - 120 mgBOD/L. Untuk IPAL yang dioperasikan secara penuh saja akan sering dijumpai kadar efluen $>$ BMLC industri tekstil $=60$ mgBOD/L yang kemudian dibuang ke perairan umum sedangkan di badan air sungai harus memenuhi KMA Kelas II $=3 \mathrm{mgBOD} / \mathrm{L}$ (PP No. 82/2001). Di sisi lain para pembuang limbah sudah merasa memenuhi BMLC yang belum memikirkan kondisi di badan airnya "tercemar sangat berat" apa lagi pada musim kemarau dengan debit minimum sungai yang sangat kecil.

Hal ini telah ditawarkan sejak tahun 1990-an ke pihak industri untuk melakukan diversifikasi produk basah ke kering misalkan dari pabrik tekstil dying (pencelupan) menjadi usaha garment ataupun relokasi ke daerah yang masih mempunyai DTBPA yang cukup memadai. Selain hal tersebut sering pula dipromosikan "Stop standar ganda"......... "gunakan hanya baku mutu air di badan air/sumber air" atau juga ZWM (Zero Waste Management) dan untuk daerah yang tercemar juga terkena banjir dapat dipromosikan "Zero $\Delta q$ policy".

Berdasarkan uraian di atas, dimensi teknis ini baru sedikit sekali mengimplementasikan berbagai kegiatannya, memang baru studi PKA dan sangat sedikit capaian kinerjanya dalam mereduksi beban pencemar, memang hasil analisis dengan indeks "Kurang berkelanjutan" dan untuk mengejar ketinggalannya harus memacu atribut leverage-nya guna meningkatkan indeks keberlanjutannya. Seperti halnya pada dimensi kebijakan, perkiraan yang mungkin dapat dilakukan pada tahun 2030 dan tahun 2050 terlihat ada peningkatan upaya walaupun sulit diperkirakannya sehubungan kinerja operasional pelaksanaan PPA di Citarum selama ini hanya sebatas program saja.

Berdasarkan hasil kuesioner, dengan input Tabel 4 kolom 5 untuk tahun 2030 yang diolah dengan MDS menghasilkan: $I_{k}=63,92 \%$ (cukup berkelanjutan) dengan nilai stress: $S_{k}=0,1981$ (memenuhi $<0,25$ ) dan $R^{2}=0,9329$ (sangat bermakna pada $\mathrm{p}<0,005$ ). Selanjutnya untuk input dari Tabel 4 kolom 6 untuk tahun 2050 menghasilkan: $I_{k}=78,06 \%$ (sangat berkelanjutan) dengan nilai stress: $S_{k}=0,1253$ (memenuhi $<0,25$ ) dan $R^{2}=0,9422$ (sangat bermakna pada $\mathrm{p}<0,002$ ).

\section{Status Keberlanjutan Dimensi Ekonomi}

Dimensi ekonomi menyertakan 6 atribut yang dikelompokan dalam tiga aspek seperti pada Tabel 1. Keberlanjutan upaya PPA sangat penting untuk masyarakat yang tinggal di tepian sungai/anak sungai (riparian) Citarum terkait dengan atribut daya beli masyarakat dan pemanfaatan limbah. Hal ini dimaksudkan agar para riparian sejahtera dan tentunya diharapkan lingkungan di tepian sungai menjadi higienis, sebetulnya atribut ini ada hubungannya dengan kebijakan pemerintah untuk menyediakan sarana sanitasi seperti pada dimensi kebijakan.

Hasil perhitungan rata-rata skor yang didapatkan dari para responden secara rinci disajikan pada Tabel 5. Nilai skor secara umum 41,6\% mendekati nilai dummy, sementara yang di bawah nilai dummy sekitar $26,1 \%$ dan yang di atas nilai dummy yaitu sekitar $32,3 \%$. Selanjutnya hasil rata-rata skor dijadikan input untuk aplikasi MDS yang menghasilkan seperti pada Gambar 3.

Hasil analisis MDS untuk dimensi ekonomi pada tahun 2015 adalah $I_{k}=33,18 \%$ (kurang berkelanjutan) dengan nilai stress: $S_{k}=0,1472$ (memenuhi $<0,25$ ) dan $R^{2}=0,9507$ (sangat bermakna pada $\mathrm{p}<0,002$ ). Jika melihat hasil analisis leverage pada Gambar 3, diambil tiga atribut sensitif yaitu: Imbal jasa lingkungan melalui biaya pemulihan lingkungan daerah terkena dampak, Daya beli masyarakat berdasarkan peluang mendapatkan pekerjaan dan Pemanfaatan limbah lumpur menjadi bahan berguna.

Untuk penilaian aspek ekonomi seharusnya melihat ekonomi secara makro yaitu dengan adanya industri akan meningkatkan ekonomi baik dilihat dari peningkatan Produk Domestik Regional Bruto (PDRB) atau juga meningkatnya devisa negara, sementara di daerah industri ini malahan terjadi permasalahan limbah industrinya sendiri dan juga terkonsentrasinya manusia. Secara fakta di Citarum beban pencemar yang terbesar adalah domestik dan industri, sedangkan untuk sumber lainnya hanya kasuistis saja. Hasil analisis MDS 
Tabel 5 Hasil Kuesioner Dimensi Ekonomi pada tahun 2015, Perkiraan tahun 2030 dan 2050

\begin{tabular}{|c|c|c|c|c|c|}
\hline $\begin{array}{l}\overline{\bar{c}} \\
\stackrel{\Phi}{\Phi} \\
\dot{\underline{\Delta}}\end{array}$ & Aspek & Atribut & $\begin{array}{c}\boldsymbol{N}_{\boldsymbol{a}} \\
\text { Eksisting } \\
2015\end{array}$ & $\begin{array}{l}\boldsymbol{N}_{\boldsymbol{a}} \\
\text { Perkiraan } \\
2030\end{array}$ & $\begin{array}{c}\boldsymbol{N}_{\boldsymbol{a}} \\
\text { Perkiraan } \\
2050\end{array}$ \\
\hline$(1)$ & $(2)$ & (3) & $(4)$ & (5) & (6) \\
\hline \multirow{3}{*}{ 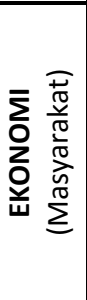 } & 1) Daya Beli Masyarakat & $\begin{array}{l}\text { - Peluang mendapatkan pekerjaan } \\
\text { - Upah yang layak }\end{array}$ & $\begin{array}{l}0,54 \\
1,12\end{array}$ & $\begin{array}{l}1,24 \\
2,44\end{array}$ & $\begin{array}{l}2,48 \\
2,85\end{array}$ \\
\hline & 2) Imbal jasa lingkungan & $\begin{array}{l}\text { - Biaya pengelolaan lingk. hulu } \\
\text { - Pemulihan daerah terdampak }\end{array}$ & $\begin{array}{l}0,84 \\
1,24\end{array}$ & $\begin{array}{l}1,12 \\
1,88\end{array}$ & $\begin{array}{l}2,28 \\
2,47\end{array}$ \\
\hline & 3) Pemanfaatan limbah & $\begin{array}{l}\text { - Sisa limbah utk pupuk cair/gas } \\
\text { methana } \\
\text { - Sisa lumpur utk bahan berguna }\end{array}$ & $\begin{array}{l}0,88 \\
0,62\end{array}$ & $\begin{array}{l}1,54 \\
1,28\end{array}$ & $\begin{array}{l}2,24 \\
2,42\end{array}$ \\
\hline
\end{tabular}
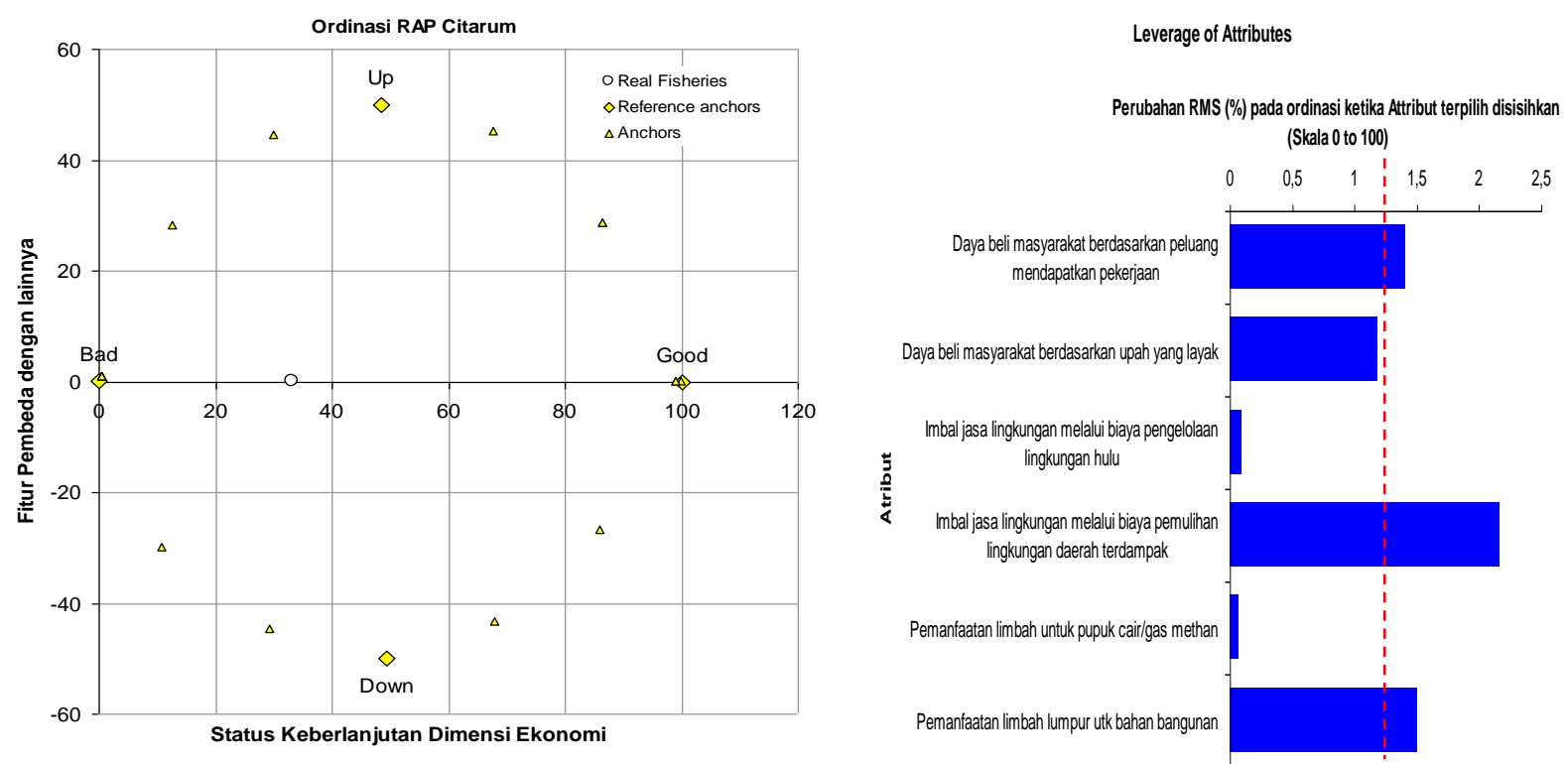

Gambar 3 Indeks Keberlanjutan Dimensi Ekonomi Tahun 2015

untuk kondisi eksisting (Tahun 2015) berdasarkan input data yang diambil dari Tabel 5 kolom 4 yaitu seperti pada Gambar 3.

Berbagai kegiatan industri lokasinya bercampur dengan masyarakat yang tinggal di sekitar tepian sungai, pada umumnya masyarakat berpenghasilan rendah yang memanfaatkan sungai sebagai sumber airnya mereka, baik memanfaatkan air secara langsung dari sungai atau juga membuat sumur gali. Jika terjadi pencemaran di sungai, yang menjadi korban umumnya mereka inilah, kalau dilihat dari dimensi teknis peluang tercemarnya sumber air sangat besar, sehingga yang perlu diteliti dampaknya terkait dengan tiga aspeknya yaitu: Daya beli masyarakat, perlunya Imbal jasa lingkungan dari industri dan pemanfaatan limbah.

Berdasarkan indeks pembangunan manusia (IPM), daya beli masyarakat selalu terkait dengan: peluang mendapatkan pekerjaan dan upah yang layak. Sedangkan aspek lainnya yaitu pemberdayaan masyarakat yang terkena dampak inilah yang perlu diprioritaskan melalui pemanfaatan limbah untuk dijadikan pupuk cair atau pemanfaatan gas methana atau juga lumpur sebagai by product dari proses IPAL menjadi bahan yang berguna. Selain itu juga masyarakat sebagai pekerja dalam kegiatan imbal jasa lingkungan.

Untuk dimensi ekonomi, perkiraan yang mungkin dapat dilakukan pada tahun 2030 dan tahun 2050, yang berdasarkan hasil kuesioner seperti pada Tabel 5 kolom 5 yaitu merupakan input data MDS untuk tahun 2030 adalah: $I_{k}=$ 44,98\% (kurang berkelanjutan) dengan nilai stress: $S_{k}=0,1554$ (memenuhi $<0,25$ ) dan $R^{2}=0,9457$ (sangat bermakna pada $\mathrm{p}<0,005$ ). Selanjutnya untuk input dari Tabel 5 kolom 6 yaitu tahun 2050 adalah: $I_{k}=53,87 \%$ (cukup berkelanjutan) dengan nilai stress: $S_{k}=0,1571$ (memenuhi $<0,25$ ) dan $R^{2}=$ 0,9446 (sangat bermakna pada $\mathrm{p}<0,002$ ).

\section{Status Keberlanjutan Dimensi Sosial Budaya}

Dimensi sosial-budaya menyertakan 8 atribut yang dikelompokan dalam empat aspek 
Tabel 6 Hasil Kuesioner Dimensi Sosial-Budaya tahun 2015, Perkiraan tahun 2030 dan 2050

\begin{tabular}{|c|c|c|c|c|c|}
\hline $\begin{array}{l}\bar{y} \\
\bar{d} \\
\frac{E}{0}\end{array}$ & Aspek & Atribut & $\begin{array}{c}\boldsymbol{N}_{\boldsymbol{a}} \\
\text { Eksisting } \\
2015\end{array}$ & $\begin{array}{c}\boldsymbol{N}_{\boldsymbol{a}} \\
\text { Perkiraan } \\
2030\end{array}$ & $\begin{array}{c}\boldsymbol{N}_{\boldsymbol{a}} \\
\text { Perkiraan } \\
2050\end{array}$ \\
\hline (1) & (2) & (3) & (4) & (5) & (6) \\
\hline \multirow{4}{*}{ 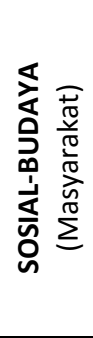 } & $\begin{array}{l}\text { 1) Tingkat pendidikan } \\
\text { masyarakat }\end{array}$ & $\begin{array}{l}\text { - Rata-rata lamanya sekolah } \\
\text { - Kejuruan yg sesuai kebutuhan }\end{array}$ & $\begin{array}{l}1,14 \\
1,28\end{array}$ & $\begin{array}{l}1,88 \\
2,14\end{array}$ & $\begin{array}{l}2,24 \\
2,85\end{array}$ \\
\hline & $\begin{array}{l}\text { 2) Kepedulian thd } \\
\text { lingkungan }\end{array}$ & $\begin{array}{l}\text { - Tingkat kepedulian thd. Lingk. } \\
\text { - Jumlah masyarakat yang peduli }\end{array}$ & $\begin{array}{l}2,12 \\
1,42\end{array}$ & $\begin{array}{l}2,88 \\
1,94\end{array}$ & $\begin{array}{l}3,14 \\
2,21\end{array}$ \\
\hline & 3) Kontrol sosial masyarakat & $\begin{array}{l}\text { - Respon positif masyarakat } \\
\text { - Organisasi masa berbasis lingk. }\end{array}$ & $\begin{array}{l}1,22 \\
1,85\end{array}$ & $\begin{array}{l}2,24 \\
2,58\end{array}$ & $\begin{array}{l}2,86 \\
3,12\end{array}$ \\
\hline & $\begin{array}{l}\text { 4) Dukungan thd kearifan } \\
\text { lokal }\end{array}$ & $\begin{array}{l}\text { - Kreativitas lokal masyarakat } \\
\text { - Pelestarian kearifan lokal }\end{array}$ & $\begin{array}{l}1,18 \\
1,22\end{array}$ & $\begin{array}{l}1,86 \\
2,11\end{array}$ & $\begin{array}{l}2,43 \\
2,72\end{array}$ \\
\hline
\end{tabular}
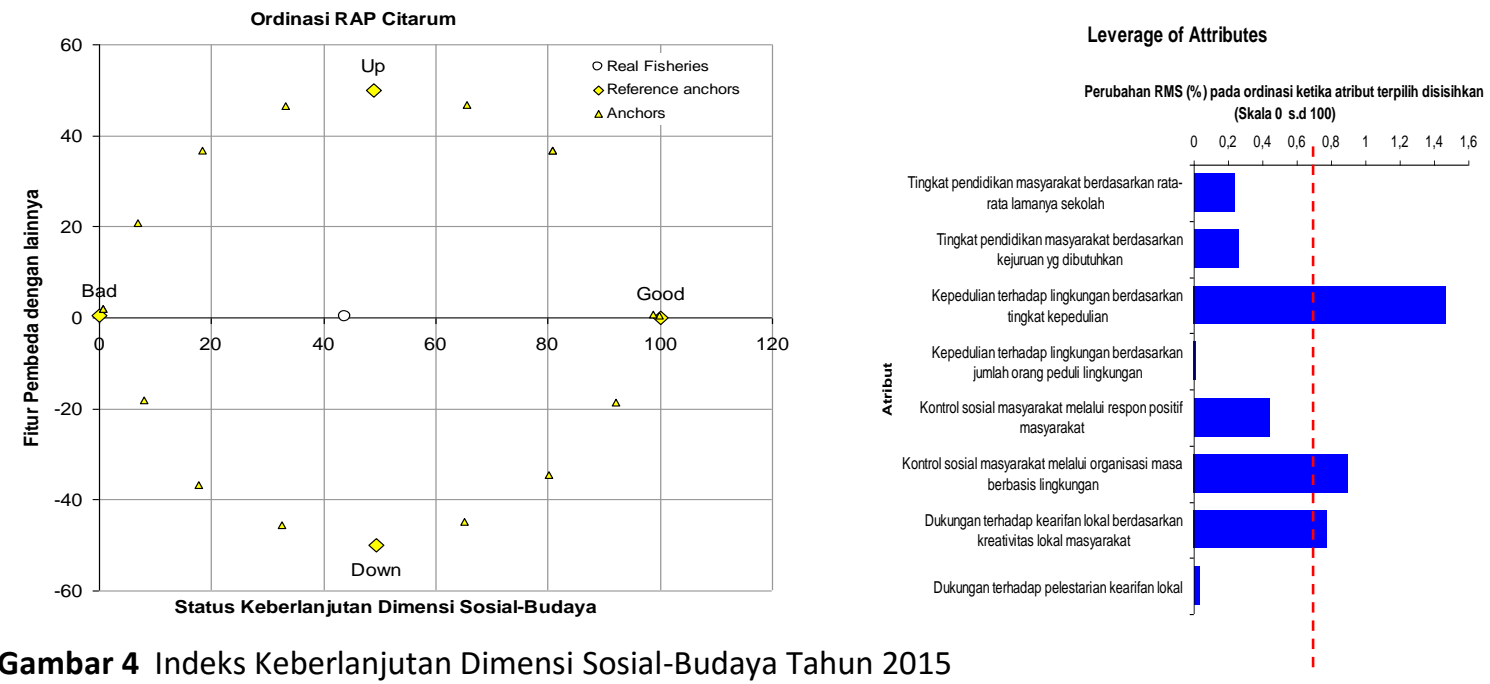

Gambar 4 Indeks Keberlanjutan Dimensi Sosial-Budaya Tahun 2015

seperti pada Tabel 1. Dimensi sosial-budaya untuk keberlanjutan upaya PPA sangat penting guna para riparian terkait atribut kepedulian terhadap lingkungan dan kontrol sosial masyarakat. Disamping itu aspek sosial-budaya terkait tingkat pendidikan masyarakat dan dukungan terhadap kearifan lokal. Adapun atribut dari masing-masing aspek dapat dilihat pada Tabel 6 kolom 3 .

Untuk dimensi sosial-budaya ini khususnya riparian jika mempunyai kepedulian lingkungan tentunya akan mengupayakan sungai Citarum menjadi lebih baik, dan pada saat terjadi pencemaran dapat dijadikan pula sebagai alat kontrol sosial untuk mengetahui kejadian pencemaran air yaitu memanfaatkan aspek budaya yang dapat dikembangkan misalnya ada kearifan lokal yang dapat diangkat sebagai budaya yang perlu dilestarikan seperti pemberitahuan kejadian pencemaran menggunakan kentongan. Sedangkan tingkat pendidikan masyarakat diharapkan dapat mengubah perilaku membuang sampah ke sungai atau juga buang hajat langsung ke sungai. Hasil analisis MDS untuk kondisi eksisting (tahun 2015) dengan input yang diambil dari Tabel 6 kolom 4, hasilnya seperti pada Gambar 4. Hasil perhitungan rata-rata skor dari para responden secara rinci disajikan pada Tabel 6 kolom 4, 5 dan 6. Nilai skor secara umum 51,2\% mendekati nilai dummy, sementara yang di bawah nilai dummy sekitar $23,4 \%$ dan yang di atas nilai dummy yaitu sekitar $25,4 \%$. Selanjutnya hasil rata-rata skor yang dijadikan input data untuk aplikasi MDS pada Dimensi Sosial-Budaya tahun 2015 yang diambil dari Tabel 6 kolom 4 menghasilkan: $I_{k}=43,81 \%$ (kurang berkelanjutan) dengan nilai stress: $S_{k}=$ 0,1575 (memenuhi $<0,25$ ) dan $R^{2}=0,9413$ (sangat bermakna pada $\mathrm{p}<0,002$ ). Jika melihat hasil analisis leverage pada Gambar 4, diambil tiga atribut sensitif yaitu: Kepedulian terhadap lingkungan berdasarkan tingkat peduli dan Kontrol sosial masyarakat melalui organisasi masa berbasis lingkungan dan Dukungan terhadap kearifan lokal berdasarkan kreativitas lokal masyarakat.

Perkiraan responden yang mungkin dapat dilakukan pada tahun 2030 dan tahun 2050. Berdasarkan hasil kuesioner, dengan data input 
seperti pada Tabel 6 kolom 5 yaitu pada tahun 2030 menghasilkan: $I_{k}=51,93 \%$ (cukup berkelanjutan) dengan nilai stress: $S_{k}=0,1604$ (memenuhi $<0,25$ ) dan $R^{2}=0,9398$ (sangat bermakna pada $\mathrm{p}<0,005)$. Selanjutnya untuk input dari Tabel 6 kolom 6 yaitu tahun 2050 menghasilkan: $I_{k}=58,13 \%$ (cukup berkelanjutan) dengan nilai stress: $S_{k}=0,1561$ (memenuhi $<0,25$ ) dan $R^{2}=0,9418$ (sangat bermakna pada $\mathrm{p}<0,002$ ). Jika melihat analisis leverage untuk tiga atribut sensitif hasilnya masih sama dengan kondisi eksisting.

\section{Status Keberlanjutan Dimensi Penegakan Hukum}

Dimensi penegakan hukum menyertakan 8 atribut yang dikelompokan dalam empat aspek seperti pada Tabel 1. Kalau dilihat beberapa kasus melalui dimensi ini seharusnya para pembuang limbah diberikan informasi atau sosialisasi peraturan-peraturan yang akan menjeratnya agar jangan sampai terjadinya kasus hukum lingkungan. Hal ini dimungkinkan juga dengan kejelasan peraturannya, ketegasan pemberlakuan hukum dan pengawasan selama operasional perorangan/badan usaha yang melibatkan penyidik pegawai negeri sipil (PPNS) ataupun jaksa.

Hasil perhitungan rata-rata skor dari para responden secara rinci disajikan pada Tabel 7 kolom 4, 5 dan 6. Nilai skor secara umum 54,2\% mendekati nilai dummy, sementara yang di bawah nilai dummy sekitar $21,4 \%$ dan yang di atas nilai dummy yaitu sekitar 24,4\%. Selanjutnya hasil ratarata skor dijadikan input pada aplikasi MDS untuk Dimensi Penegakan Hukum pada tahun 2015 menghasilkan: $I_{k}=42,95 \%$ (kurang berkelanjutan) dengan nilai stress: $S_{k}=0,1575$ (memenuhi $<0,25$ ) dan $R^{2}=0,9420$ (sangat bermakna pada $\mathrm{p}<0,002$ ). Jika melihat analisis leverage pada Gambar 5, diambil tiga atribut sensitif yaitu: Kejelasan peraturan sesuai kebutuhan Pemangku kepentingan, Peningkatan kompetensi PPNS dan Kejelasan peraturan yang transparan-efektivproporsional.

Tabel 7 Hasil Kuesioner Dimensi Penegakan Hukum tahun 2015, Perkiraan tahun 2030 dan 2050

\begin{tabular}{|c|c|c|c|c|c|}
\hline$\stackrel{\mathscr{\xi}}{\bar{a}} \overline{\underline{s}}$ & Aspek & Atribut & $\begin{array}{c}\boldsymbol{N}_{\boldsymbol{a}} \\
\text { Eksisting } \\
2015\end{array}$ & $\begin{array}{c}\boldsymbol{N}_{\boldsymbol{a}} \\
\text { Perkiraan } \\
2030\end{array}$ & $\begin{array}{c}\boldsymbol{N}_{\boldsymbol{a}} \\
\text { Perkiraan } \\
2050\end{array}$ \\
\hline (1) & (2) & (3) & (4) & (5) & (6) \\
\hline \multirow{8}{*}{ 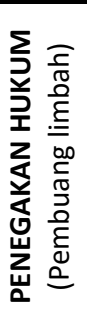 } & \multirow{2}{*}{$\begin{array}{l}\text { 1) Kejelasan } \\
\text { peraturan }\end{array}$} & \multirow{2}{*}{$\begin{array}{l}\text { - Peraturan sesuai kebutuhan } \\
\text { - Transparan, efektiv dan proporsional }\end{array}$} & 2,12 & 2,78 & 3,04 \\
\hline & & & 1,62 & 2,12 & 2,54 \\
\hline & \multirow{2}{*}{$\begin{array}{l}\text { 2) Ketegasan } \\
\text { hukum }\end{array}$} & \multirow{2}{*}{$\begin{array}{l}\text { - Pengawasan pelanggaran hukum } \\
\text { - Penindakan pelanggaran hukum }\end{array}$} & 1,48 & 2,04 & 2,44 \\
\hline & & & 1,24 & 1,86 & 2,16 \\
\hline & \multirow{2}{*}{ 3) Pengawasan } & - Jumlah PPNS & 1,22 & 1,88 & 2,22 \\
\hline & & - Kompetensi PPNS & 1,12 & 2,14 & 2,54 \\
\hline & \multirow[t]{2}{*}{ 4) Pengadilan } & - Jumlah Jaksa & 1,26 & 2,26 & 2,88 \\
\hline & & - Jumlah fasilitas pengadilan & 1,25 & 2,44 & 3,11 \\
\hline
\end{tabular}
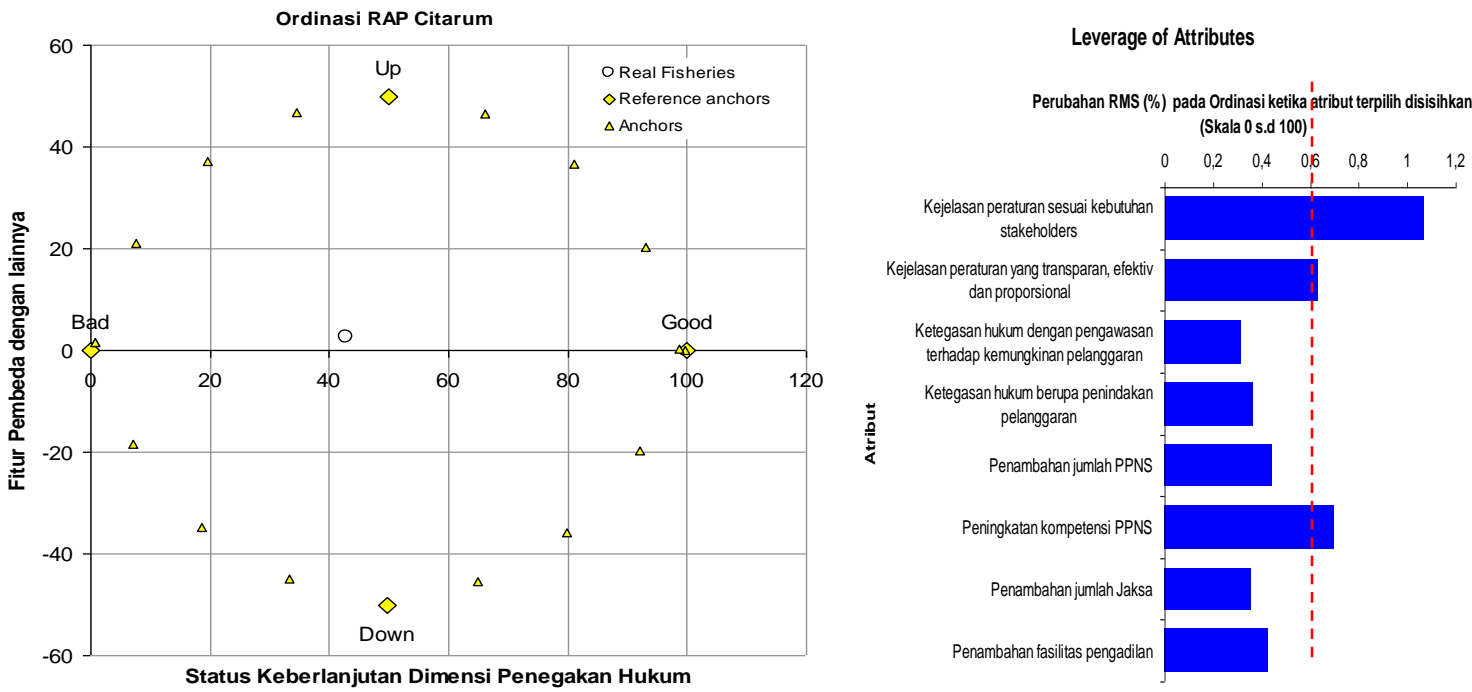

Gambar 5 Indeks Keberlanjutan Dimensi Penegakan Hukum Tahun 2015 
Berdasarkan hasil kuesioner ini perkiraan yang mungkin dapat dilakukan pada tahun 2030 dan tahun 2050 seperti pada Tabel 7 kolom 5 yaitu pada tahun 2030 menghasilkan: $I_{k}=51,12 \%$ (cukup berkelanjutan) dengan nilai stress: $S_{k}=$ 0,1597 (memenuhi $<0,25$ ) dan $R^{2}=0,9412$ (sangat bermakna pada $\mathrm{p}<0,005$ ). Selanjutnya untuk input dari Tabel 7 kolom 6 yaitu tahun 2050 menghasilkan: $I_{k}=55,92 \%$ (cukup berkelanjutan) dengan nilai stress: $S_{k}=0,1557$ (memenuhi < 0,25) dan $R^{2}=0,9431$ (sangat bermakna pada $\mathrm{p}<0,002$ ).

\section{Status Keberlanjutan Dimensi Dukungan Pemangku Kepentingan}

Dimensi dukungan pemangku kepentingan menyertakan delapan atribut yang dikelompokan dalam empat aspek yaitu: Program PPA partisipatif, Program CSR, Program Advis Teknis dan Sistem Informasi Lingkungan. Dukungan ini dapat merupakan kegiatan berbagai pihak yang bersifat partisipativ misalnya asosiasi profesi sebagai aktor yang komit melakukan PPA dengan memberikan: dukungan, bantuan konsep, hasil litbang atau dukungan terhadap masyarakat yang terkena dampak. Lain halnya program CSR umumnya sudah merupakan program dari suatu lembaga misalnya industri melaksanakan penanaman pohon atau bakti sosial. Selain itu ada pula yang memberikan dukungan advis teknis atau pembinaan teknologi serta adanya sistem informasi lingkungan sebagai sumbangan informasi kepada publik.

Hasil perhitungan rata-rata skor dari para responden secara rinci disajikan pada Tabel 8 kolom 4, 5 dan 6 . Nilai skor secara umum 51,3\% mendekati nilai dummy yang diberikan sebagai contoh, sementara yang di bawah nilai dummy sekitar 19,8\% dan yang di atas nilai dummy yaitu sekitar 28,9\%. Selanjutnya hasil rata-rata skor yang dijadikan input pada aplikasi MDS untuk Dimensi Dukungan Pemangku Kepentingan pada tahun 2015 menghasilkan: $I_{k}=42,97 \%$ (kurang berkelanjutan) dengan nilai stress: $S_{k}=0,1562$ (memenuhi $<0,25$ ) dan $R^{2}=0,9430$ (sangat bermakna pada $\mathrm{p}<0,001$ ). Jika melihat hasil analisis leverage pada Gambar 6, diambil tiga atribut sensitif yang RMS-nya paling besar yaitu: Sistem informasi lingkungan yang didukung dengan informasi yang akurat, Sistem informasi lingkungan yang selalu mutakhir dan PPA partisipativ dengan dukungan penuh pada masyarakat yang terkena dampak. Hasil analisis MDS untuk kondisi eksisting (tahun 2015) dengan input yang diambil dari Tabel 8 kolom 4, seperti pada Gambar 6.

Berdasarkan hasil kuesioner ini perkiraan yang mungkin dapat dilakukan pada tahun 2030 dan tahun 2050 seperti pada Tabel 8 kolom 7 yaitu pada tahun 2030 menghasilkan: $I_{k}=49,14 \%$ (kurang berkelanjutan) dengan nilai stress: $S_{k}=$ 0,1582 (memenuhi $<0,25$ ) dan $R^{2}=0,9422$ (sangat bermakna pada $\mathrm{p}<0,005$ ). Selanjutnya untuk input dari Tabel 8 kolom 8 yaitu tahun 2050 adalah: $I_{k}=$ $53,67 \%$ (cukup berkelanjutan) dengan nilai stress: $S_{k}=0,1557$ (memenuhi $<0,25$ ) dan $R^{2}=0,9434$ (sangat bermakna pada $\mathrm{p}<0,002$ ). Jika melihat hasil analisis leverage untuk tiga atribut sensitif masih sama seperti pada kondisi eksistingnya.

Setelah membahas analisis keberlanjutan untuk berbagai dimensi yaitu: Kebijakan, Teknis, Ekonomi, Sosial-Budaya, Penegakan Hukum dan Dukungan Pemangku Kepentingan. Selanjutnya Rekapitulasi akhir untuk berbagai dimensi seperti terlihat pada Tabel 9 dan Gambar 7.

Tabel 8 Hasil Kuesioner Dimensi Dukungan Pemangku Kepentingan tahun 2015, Perkiraan tahun 2030 dan 2050

\begin{tabular}{|c|c|c|c|c|c|}
\hline Dimensi & Aspek & Atribut & $\begin{array}{c}\boldsymbol{N}_{\boldsymbol{a}} \\
\text { Eksisting } \\
2015\end{array}$ & $\begin{array}{c}\boldsymbol{N}_{\boldsymbol{a}} \\
\text { Perkiraan } \\
2030\end{array}$ & $\begin{array}{c}\boldsymbol{N}_{\boldsymbol{a}} \\
\text { Perkiraan } \\
2050\end{array}$ \\
\hline (1) & (2) & (3) & (4) & (5) & (6) \\
\hline \multirow{8}{*}{ 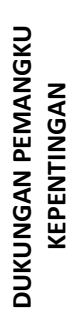 } & 1) Program PPA & - Aktor pelaku vang komit PPA & 2,12 & 2,78 & 3,04 \\
\hline & Partisipatif & - Dukungan terhadap masyarakat terkena dampak & 1,62 & 2,12 & 2,54 \\
\hline & 2) Program CSR & - Prioritas pelaksanaan CSR sesuai kebutuhan & 1,48 & 2,04 & 2,44 \\
\hline & & - Alokasi biaya yang transparan dan efektiv & 1,24 & 1,86 & 2,16 \\
\hline & 3) Program Advis & - Dukungan instansi terkait & 1,22 & 1,88 & 2,22 \\
\hline & teknis & - Keberlanjutan advis dan pembinaan teknologi & 1,12 & 2,14 & 2,54 \\
\hline & 4) Sistem Informasi & - Keakuratan informasi & 1,26 & 2,26 & 2,88 \\
\hline & Lingkungan & - Ke-mutakhir-an informasi & 1,25 & 2,44 & 3,11 \\
\hline
\end{tabular}



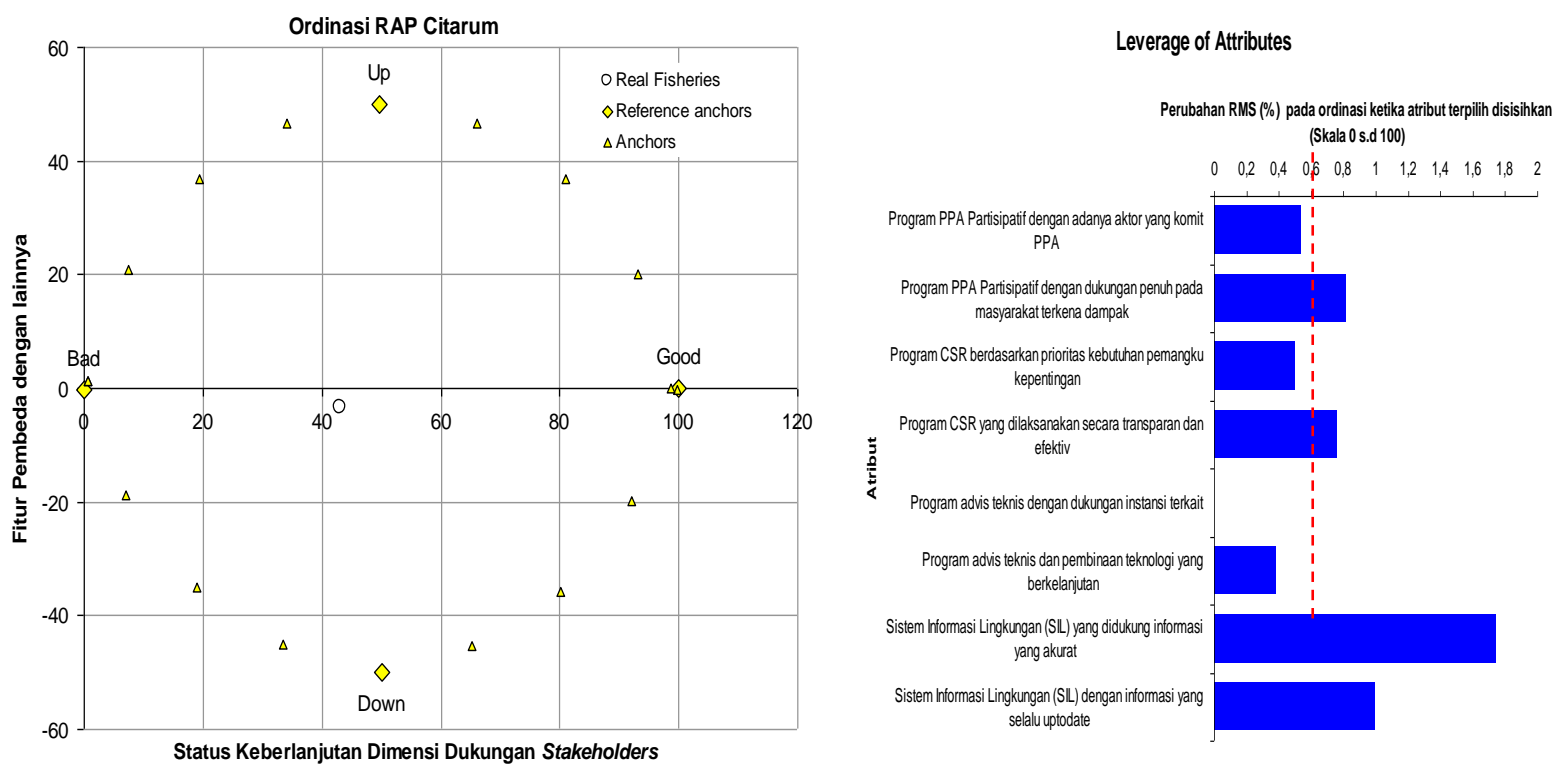

Gambar 6 Indeks Keberlanjutan Dimensi Dukungan Pemangku Kepentingan Tahun 2015

Tabel 9 Rekapitulasi Hasil Indeks Keberlanjutan Pelaksanaan PPA Citarum

\begin{tabular}{c|l|c|c|c}
\hline \multirow{2}{*}{ No } & \multicolumn{1}{|c|}{ Dimensi } & \multicolumn{3}{|c}{ Indek Keberlanjutan $\left(\boldsymbol{I}_{\boldsymbol{k}} \mathbf{)}\right.$} \\
\cline { 3 - 4 } & & Tahun 2015 & Tahun 2030 & Tahun 2050 \\
\hline 1. & Kebijakan & $46,52 \%$ & $61,47 \%$ & $69,49 \%$ \\
\hline 2. & Teknis & $46,50 \%$ & $63,92 \%$ & $78,06 \%$ \\
\hline 3. & Ekonomi & $33,18 \%$ & $44,98 \%$ & $53,87 \%$ \\
\hline 4. & Sosial - Budaya & $43,81 \%$ & $51,93 \%$ & $58,13 \%$ \\
\hline 5. & Penegakan Hukum & $42,95 \%$ & $51,12 \%$ & $55,92 \%$ \\
\hline 6. & Dukungan Pemangku kepentingan & $42,97 \%$ & $49,41 \%$ & $53,67 \%$ \\
\hline
\end{tabular}

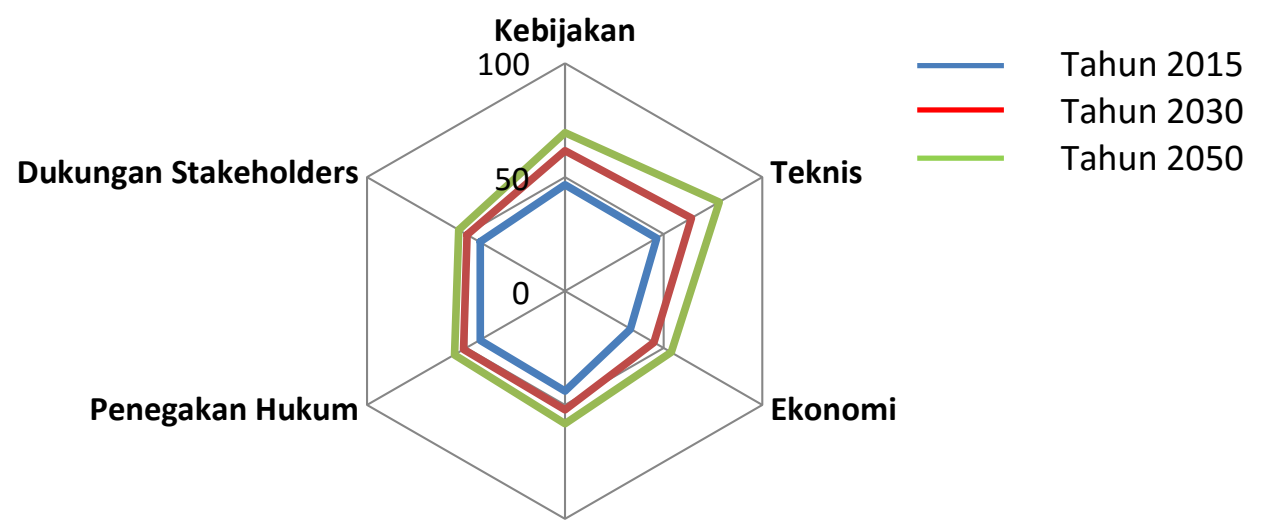

Sosial - Budaya

Gambar 7 Indeks Keberlanjutan Upaya PPA Citarum Tahun 2015, 2030 dan 2050

\section{KESIMPULAN}

Hasil penelitian ini dapat memberikan gambaran bahwa kompleksitas permasalahan Sungai Citarum menjadi kendala besar untuk melaksanakan berbagai upaya PPA dalam rangka keberlanjutan pengelolaan kualitas air. Hasil analisis keberlanjutan untuk kondisi eksisting tahun 2015, semua dimensi "kurang berkelanjutan", namun untuk perkiraan tahun 2030 dan 2050 para responden sedikit optimis diwaktu mendatang ada peningkatan upaya pada dimensi teknis meningkat signifikan mencapai status "sangat berkelanjutan" dan diikuti oleh dimensi lainnya mencapai status "cukup berkelanjutan".

Hasil analisis ada indikasi bahwa dimensi 
teknis dapat diimplementasikan lebih mudah dari pada dimensi lainnya seperti: sosial-budaya, penegakan hukum dan yang tersulit adalah dimensi ekonomi. Untuk meningkatkan status keberkelanjutannya perlu memacu atribut-atribut sensitif hasil dari analisis leverage (misal atribut peningkatan DTBPA melalui pemanenan air hujan pada dimensi Teknis) dengan mempertimbangkan pula keseimbangan atribut lain pada setiap dimensinya.

\section{DAFTAR PUSTAKA}

Edwarsyah, 2008. Rancang Bangun Sistem Kebijakan Pengelolaan DAS dan Pesisir, Studi Kasus: DAS dan Pesisir Citarum Jawa Barat [disertasi]. Bogor: Program Pascasarjana, Institut Pertanian Bogor.

Hasan, Mohamad. et.all. 2011. Model Pengelolaan Sumber Daya Air DAS Citarum Yang Berkelanjutan, Jurnal Sumber Daya Air. Bandung. Volume 7 No. 2, November 2011.

Hooper, Bruce P. 2003. Integrated Water Resources Management and River Basin Governance. Journal Water Resources Update, Issue 126, Pages 12-20, November 2003, Southern Illinois University Carbondale.

Kavanagh P. 2001. Rapid Appraisal of Fisheries (RAPFISH) Project. University of British Columbia, Fisheries Centre.

Peraturan Daerah No. 21 Tahun 2007 Tentang Pembentukan Organisasi Lembaga Teknis Daerah Kabupaten Bandung. Soreang.

Peraturan Gubernur Jawa Barat No. 51 Tahun 2009, Tentang Tugas dan fungsi BPLHD Provinsi Jawa Barat. Bandung.

Peraturan Pemerintah Republik Indonesia No. 70 Tahun 2010 tentang Perum Jasa Tirta II

Peraturan Pemerintah Republik Indonesia No.82 Tahun 2001 tentang Pengelolaan Kualitas Air dan Pengendalian Pencemaran Air.

Peraturan Menteri PU No.21/PRT/M/2010 tentang Organisasi dan Tata Kerja Unit Pelaksana Teknis Kementerian PU. 2010.

Pitcher, T.J. and Preikshot, D.B. 2001. Rapfish: A Rapid Appraisal Technique to Evaluate the Sustainability Status of Fisheries. Fisheries Research 49(3): 255-270
Pusat Litbang SDA. 2012. Data Kualitas Air, DAS Citarum. Balai Lingkungan Keairan. Bandung.

Pusat Litbang SDA. 2012. Data Debit Rata-rata Harian, DAS Citarum. Balai Hidrologi dan Tata Air. Bandung.

Pusat Litbang SDA. 2015. Penyusunan Naskah Kebijakan Pengendalian Pencemaran Air Sungai Citarum. Laporan Hasil Litbang Tahun Anggaran 2015. Bandung

Rachman, 2012. Panduan Rapfish. Pelatihan penggunaan Model Multi Dimensional Scalling, Bapenas, Jakarta.

Ridwan, WA. 2006. Model Agribisnis Peternakan Sapi Perah Berkelanjutan pada Kawasan Pariwisata di Kabupaten Bogor. Studi Kasus Kecamatan Cisarua dan Megamendung Bogor: Program Pascasarjana, Institut Pertanian Bogor.

Sabiham S. 2005. Manajemen sumber daya lahan dalam usaha pertanian berkelanjutan. Makalah seminar Nasional Himpunan Mahasiswa Ilmu Tanah "Save our Land for the Better Environment". Bogor.

Soegandy, A dan Hakim, R. 2007. Prinsip Dasar Kebijakan Pembangunan Berkelanjutan Berwawasan Lingkungan. Penerbit Bumi Aksara. Jakarta

Undang-Undang Republik Indonesia No. 32 Tahun 2009, tentang Perlindungan dan Pengelolaan Lingkungan Hidup.

\section{UCAPAN TERIMA KASIH}

Penulis mengucapkan terima kasih dan penghargaan kepada BPLHD Provinsi Jawa Barat, BPLH Kabupaten Bandung, Dinas PSDA Provinsi Jawa Barat, BBWS Citarum dan PJT-II yang telah mendiskusikan program penelitian ini serta membantu melakukan evaluasi internal yang dijadikan input pada analisis upaya PPA Sungai Citarum dengan model MDS ini. Terima kasih disampaikan kepada Bapak Ir. Supardiono Sobirin yang memberikan arahan berbagai aspek dan atribut dari masing-masing dimensi serta saya sampaikan pula terima kasih kepada Dr. Rachman Kurniawan yang memberikan bimbingan penggunaan Raffish, dan semua pihak yang telah membantu penyelesaian makalah ini. 